Review

\title{
Synthesis of Copper Nanocluster and Its Application in Pollutant Analysis
}

\author{
Yan Xue ${ }^{1, \dagger}{ }^{+}$Zehua Cheng ${ }^{1, \dagger}$, Mai Luo ${ }^{1}$, Hao Hu ${ }^{1, *}$ and Chenglai Xia ${ }^{2,3, *}$ \\ 1 State Key Laboratory of Quality Research in Chinese Medicine, Institute of Chinese Medical Sciences, \\ University of Macau, Macau 999078, China; yc17538@um.edu.mo (Y.X.); yb87516@um.edu.mo (Z.C.); \\ yc07547@um.edu.mo (M.L.) \\ 2 Affiliated Foshan Maternity \& Child Healthcare Hospital, Southern Medical University, Foshan 528000, China \\ 3 School of Pharmaceutical Sciences, Southern Medical University, Guangzhou 510150, China \\ * Correspondence: haohu@um.edu.mo (H.H.); xiachenglai@smu.edu.cn (C.X.) \\ + These authors contributed equally to this work.
}

check for updates

Citation: Xue, Y.; Cheng, Z.; Luo, M.; $\mathrm{Hu}, \mathrm{H} . ; \mathrm{Xia}, \mathrm{C}$. Synthesis of Copper Nanocluster and Its Application in Pollutant Analysis. Biosensors 2021, 11, 424. https://doi.org/10.3390/ bios11110424

Received: 16 October 2021

Accepted: 26 October 2021

Published: 28 October 2021

Publisher's Note: MDPI stays neutral with regard to jurisdictional claims in published maps and institutional affiliations.

Copyright: (c) 2021 by the authors. Licensee MDPI, Basel, Switzerland. This article is an open access article distributed under the terms and conditions of the Creative Commons Attribution (CC BY) license (https:// creativecommons.org/licenses/by/ $4.0 /)$.

\begin{abstract}
Copper nanoclusters ( $\mathrm{Cu}$ NCs) with their inherent optical and chemical advantages have gained increasing attention as a kind of novel material that possesses great potential, primarily in the use of contaminants sensing and bio-imaging. With a focus on environmental safety, this article comprehensively reviews the recent advances of $\mathrm{Cu}$ NCs in the application of various contaminants, including pesticide residues, heavy metal ions, sulfide ions and nitroaromatics. The common preparation methods and sensing mechanisms are summarized. The typical high-quality sensing probes based on $\mathrm{Cu}$ NCs towards various target contaminants are presented; additionally, the challenges and future perspectives in the development and application of $\mathrm{Cu}$ NCs in monitoring and analyzing environmental pollutants are discussed.
\end{abstract}

Keywords: sensor; fluorescence; pollutant; nanocluster; environmental analysis; pesticide; heavy metal; sulfide; explosive

\section{Introduction}

Metal nanoclusters (MNCs) with ultra-small and tunable sizes, excellent photoluminescent efficiency, long fluorescence lifespan, desirable physical and biochemical stability and relatively low toxicity, have prompted the great advancement of research in both theoretical and practical fields [1,2]. The last decade witnessed the successful synthesis of novel MNCs and their applications in fluorescent sensors mainly based on gold ( $\mathrm{Au}$ ) and silver (Ag) nanoclusters. Meanwhile, copper nanoclusters ( $\mathrm{Cu} \mathrm{NCs}$ ) have gradually gained increasing attention due to their chemical similarity with Ag NCs and Au NCs, distinct fluorescent characteristics, and in particular the low-cost and easier accessibility of their precursors as well as facile preparation procedures [3,4]. With the help of various functional ligands, it is possible to tune their emission wavelengths and obtain highly photoluminescent nanoclusters, providing potential for large-scale applications. More importantly, $\mathrm{Cu}$ NCs possess additional merits over other noble metal clusters with their excellent biocompatibility $[5,6]$. The fluorescent probes based on $\mathrm{Cu}$ NCs have demonstrated their versatility in sensing, lighting and bioimaging in clinical diagnosis and treatment [6-9]. Meanwhile, the significance of monitoring and analyzing various contaminants for the purpose of environmental safety should also be emphasized due to the widespread application of $\mathrm{Cu}$ NCs in this field.

In this review, we emphasize the recent progress of $\mathrm{Cu}$ NCs for application in environmental analysis. We first make a brief introduction of the common synthesis approaches of $\mathrm{Cu}$ NCs with a highlight on their intriguing optical properties. In the second section, we categorize the mainstream strategies based on Cu NCs in terms of sensing mechanisms. In the following part, we mainly present several typical novel $\mathrm{Cu}$ NCs targeting various contaminants in the environment, including pesticides, heavy metals, sulfide anions, as well as 
aromatic compounds. In the end, we conclude the article by discussing the challenges and prospects in the future development of $\mathrm{Cu}$ NCs as sensors for environmental pollutants.

\section{Preparation Methods and Sensing Mechanism of $\mathrm{Cu}$ NCs}

2.1. Preparation Methods

\subsubsection{Blue Emission}

In the recent decade, various fluorescent $\mathrm{Cu}$ NCs with a wide range of emission wavelengths from blue to red were developed with employment of different ligands and templates (Scheme 1). Cu NCs with blue emitting fluorescence have been covered most frequently in the latest research $[7,10-13]$. They are reported to have a broad range of applications, including detection of various contaminants and bioimaging [9,14-17]. The first blue emitting $\mathrm{Cu}$ NCs were reported in 2011 with bovine serum albumin (BSA) as template [18]. This novel type of nanocluster was synthesized in a one-pot method by using $\mathrm{CuSO}_{4}$ and $\mathrm{BSA}$ aqueous solution in the presence of $\mathrm{NaOH}$. The as-prepared $\mathrm{Cu}$ NCs showed luminescence emission maxima at $410 \mathrm{~nm}$ with a high quantum yield of $15 \%$. MALDI-TOF mass spectrometry was utilized to determine the precise atom number of the copper core. And the composition of this $\mathrm{Cu} N C$ s include $\mathrm{Cu}_{5}$ and $\mathrm{Cu}_{13}$. Since BSA is a very popular protein template in the synthesis of metal nanoclusters, many other BSA-Cu NCs with blue luminescence were subsequently reported $[12,19,20]$. Apart from proteins, thiolate ligands were also used widely to prepare Cu NCs $[17,21-24]$. In this category, glutathione (GSH) was a typical one [25-27]. In a study, $\mathrm{Cu}$ NCs with strong blue fluorescence were synthesized with GSH as both stabilizing and reducing agent [13]. These GSH-Cu NCs exhibit good photostability and storage stability with a quantum yield of $10.6 \%$. Yang's group reported their successful fabrication of $\mathrm{Cu}$ NCs stabilized with L-cysteine for the first time in a simple and green method. The most notable advantage of this material is that the L-cysteine-capped $\mathrm{Cu}$ NCs could be stored for more than 3 months in powder form without perceptible changes in their optical property. Moreover, a series of bi-ligand $\mathrm{Cu}$ NCs were developed using both thiosalicylic acid and cysteamine as protective and reducing agents [21]. The quantum yields of the products varied from $18.9 \%$ to $34.0 \%$ with the increase in cysteamine portion. This phenomenon results from the electron transfer to copper inducted by cysteamine's terminal amine. Simultaneously, the thiosalicylic acid ligand absorbs energy through aromatic ring. Thus, more energy was released in the case of a higher cysteamine ratio. Interestingly, a pH-dependent synthesis method was reported that could produce $\mathrm{Cu}$ NCs with blue or yellow fluorescence emission under basic or acidic environments [28]. The two nanoclusters were obtained with the same method using trypsin as template and hydrazine hydrate as a reducing agent. The difference in $\mathrm{pH}$ value influences the conformational states of trypsin, and consequently results in the formation of $\mathrm{Cu}$ NCs with different sizes and fluorescent properties. And the fluorescence intensity of the trypsin-templated $\mathrm{Cu}$ NCs was further improved by adjustment of several synthesis conditions, such as molar ratio of $\mathrm{CuSO}_{4} / \mathrm{N}_{2} \mathrm{H}_{4}$, reaction temperature and reaction time. A pH-dependent $\mathrm{Cu} \mathrm{NC}$ was synthesized in the presence of lysozyme and $\mathrm{NaBH}_{4}$. The $\mathrm{Cu}$ NCs showed potential in $\mathrm{pH}$ sensing since its fluorescence intensity increases with the decrease in $\mathrm{pH}$ [29]. In another study, a bright-blue $\mathrm{Cu} \mathrm{NCs}$ was prepared with lysozyme as stabilizer and $\mathrm{N}_{2} \mathrm{H}_{4}$ as reducing agent. The $\mathrm{Cu}$ NCs were pH-stable and successfully applied in Hela cell labeling [30]. 


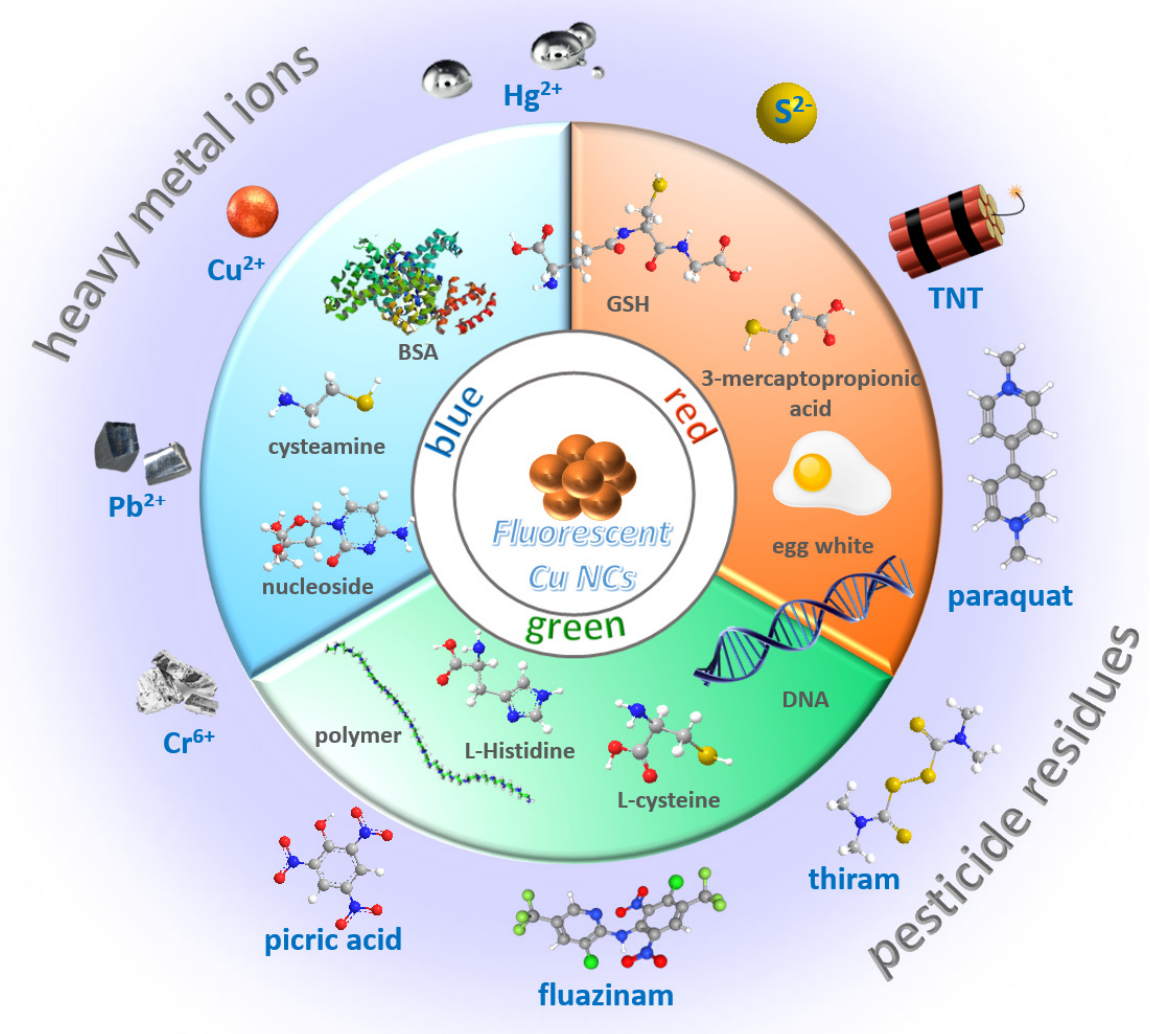

Scheme 1. Summary of ligands and templates for $\mathrm{Cu}$ NCs and their typical applications.

\subsubsection{Green Emission}

Green emitting $\mathrm{Cu} / \mathrm{Ag}$ bimetallic nanoclusters were synthesized by Mao et al. using DNA as template with the assistance of $\mathrm{NaBH}_{4}$ [31]. In this work, a series of DNA-Ag NCs and DNA-Cu/Ag NCs were prepared with several different single-stranded C-rich DNA templates. The fluorescence emission of the nanoclusters varies from green to orange. The study found that the nanoclusters with longer emission wavelengths tend to be constructed by templates with more consecutive cytosine bases. Another research designed $\mathrm{Cu}$ NCs protected by a polymer via a special UV-light-induced synthesis approach [32]. The synthesis procedure was simple and facile. $\mathrm{Cu}$ NCs were obtained through reduction of $\mathrm{Cu}\left(\mathrm{NO}_{3}\right)_{2}$ with ascorbic acid (AA) in the presence of polyethyleneimine (PEI) under UV light irradiation. Compared with stirring method, the PEI-Cu NCs prepared by UV-lightinduced approach displayed higher quantum yield and significantly enhanced fluorescence intensity. By the means of UV-light irradiation, the absolute quantum yield of PEI-Cu NCs was raised from $0.98 \%$ to $2.63 \%$ and its fluorescence intensity increased 3.7 times. Additionally, some amino acid ligands such as cysteine and histidine were also employed in the development of green emitting $\mathrm{Cu}$ NCs $[33,34]$. In an intriguing case, $\mathrm{pH}$-stimulusresponsive $\mathrm{Cu}$ NCs were fabricated using L-cysteine and chitosan as ligands [35]. The as-prepared $\mathrm{Cu}$ NCs exhibited orange-red luminescence emission at $\mathrm{pH} 4.5$, and showed cyan-green emission with aggregation-induced emission (AIE) behavior when the $\mathrm{pH}$ was above 7.4. The special phenomenon results from the weakening of H-bonding between carboxylic group of cysteine and the protonated amine moiety of chitosan caused by $\mathrm{pH}$ adjustment to 7.4. The stable overall environment around the cluster core was disrupted, leading to the formation of aggregates. Furthermore, the change in interatomic bond distance in the aggregation state brought about a blue shift of emission, and as a result, green luminescence emission was generated. 


\subsubsection{Orange/Red Emission}

Many research groups developed GSH capped Cu NCs with orange or red fluorescence emission [36-38]. A one-pot sonochemical synthesis method was established for the preparation of GSH-Cu NCs by Wang et al. [39]. In this method, $\mathrm{Cu}\left(\mathrm{NO}_{3}\right)_{2}$ and GSH were mixed in water by 1: 4 ratio, and the $\mathrm{pH}$ of solution was adjusted to 6 with $\mathrm{NaOH}$. The reaction was conducted in $15 \mathrm{~min}$ via ultrasonic irradiation, which is facile, fast and easy to operate. The as-synthesized GSH-Cu NCs exhibits bright red luminescence at $\lambda_{\max }=606 \mathrm{~nm}$ and quantum yield up to $5.3 \%$. As mentioned above, there are also many fluorescent GSH-Cu NCs that have been reported with blue emission. The main difference in the synthesis process is that red emitting GSH-Cu NCs utilized GSH as both a stabilizing and a reducing agent in acidic condition, while blue emitting ones were synthesized in basic condition or reduced by AA. DNA template is also frequently exploited in the fabrication of $\mathrm{Cu}$ NCs with red emission [40-43]. Li et al. developed copper nanoclusters templated by poly(thymine)-DNA with a fluorescence emission of $627 \mathrm{~nm}$ [44]. The DNA-Cu NCs were produced by a facile reaction between copper sulfate and poly-T DNA in 3-(N-morpholino) propanesulfonic acid buffer with the help of sodium ascorbate. Intriguingly, a research group successfully synthesized $\mathrm{Cu}$ NCs with strong orange emission utilized egg white as template [45]. The formation of $\mathrm{Cu}$ NCs relies on the interaction between multiple functional groups in egg white and $\mathrm{CuSO}_{4}$. Hydrazine hydrate was employed as reducing agent and $\mathrm{NaOH}$ was used to provide the basic environment. The reaction proceeded extremely fast, since it is carried out under microwave.

\subsubsection{Near Infrared Emission}

In recent years, some $\mathrm{Cu}$ NCs showing near infrared emission have also been developed and applied in fluorescent sensors. Li et al. reported novel $\mathrm{Cu}$ NCs using denatured bovine serum albumin (dBSA) as templates [46]. The reaction was carried out at room temperature with hydrazine hydrate as reducing agent. In particular, the denatured BSA could form $\mathrm{Cu}$ NCs more efficiently, since it possesses more free cysteine with -SH groups than BSA. The as-prepared nanoclusters were successfully utilized to detect heparin by aggregation-induced quenching mechanism. Another study synthesized a near infrared emitting copper nanocluster co-protected by thiolate and phosphine ligands [47]. The structure of this nanocluster is atomically precise with the formula of $\left[\mathrm{Cu}_{15}\left(\mathrm{PPh}_{3}\right)_{6}(\mathrm{PET})_{13}\right]^{2+}$. The product shows bright photoluminescence at $720 \mathrm{~nm}$ with crystallization induced emission enhancement property. More importantly, this research established a controllable synthesis strategy for atomically precise $\mathrm{Cu}$ NCs, which is meaningful and instructive to further study of their optical properties.

\subsection{Sensing Mechanisms}

\subsubsection{Turn Off}

On account of the prominent fluorescence property and cost-effectiveness of $\mathrm{Cu}$ NCs, numerous $\mathrm{Cu}$ NCs-based sensing probes have been developed for multitude of analytes. The majority of $\mathrm{Cu}$ NCs-based fluorescent sensors follow turn-off mechanism that the analytes are detected due to the decrease in fluorescence intensity.

Inner filter effect (IFE) is a most common strategy in the development of turn-off sensors [48-51]. The inner filter effect refers to the fluorescence quenching process that the quencher absorbs the emission or excitation light of fluorophore. A study in this context established a label-free assay for nitrofurantoin using adenosine-stabilized Cu NCs [16]. Nitrofurantoin's UV absorption band located at 250-430 $\mathrm{nm}$ happens to overlap the $\mathrm{Cu}$ NCs' fluorescence excitation and emission spectra. In this way, the excitation and emission light could be shielded by nitrofurantoin, leading to decrease in fluorescence intensity.

Some sensing methods for the detection of electron-rich species were constructed based on the electron transfer mechanism $[44,52,53]$. Cao et al. developed tannic acid (TA) capped $\mathrm{Cu}$ NCs that could selectively detect ferric ions [52]. $\mathrm{Fe}^{3+}$ could form donor-accepter complex with the TA on the surface of $\mathrm{Cu} N C s$, leading to fluorescence quenching through 
electron transfer process, and the quenching obeys a static quenching mechanism since the fluorescence lifespan was independent of the concentration of $\mathrm{Fe}^{3+}$. The high selectivity of this sensor is related to the ferric ions' electronic structure. $\mathrm{Fe}^{3+}$ has five half-filled d orbits so that it exhibits stronger electron-accepting ability than other common ions.

Another major cause of fluorescence quenching in turn-off sensing methods is aggregationinduced quenching, which is widely employed in analysis of metal ions [26,39,54]. A GSH-Cu NCs based probe for $\mathrm{Hg}^{2+}$ was constructed based on $\mathrm{Hg}^{2+}$-induced aggregation of the nanoclusters [13]. $\mathrm{Hg}^{2+}$ linked the $\mathrm{Cu}$ NCs through the interaction with GSH ligands, leading to fluorescence quenching. According to the zeta potential measurement results, the surface charge of GSH-Cu NCs became less negative in the presence of $\mathrm{Hg}^{2+}$, which destroyed the stability of $\mathrm{Cu}$ NCs and generatesd aggregates. The aggregation was further evidenced by increased diameter in TEM and enhanced light scattering signal.

\subsubsection{Turn On}

The main strategy for turn-on sensors is a signal off-on process that the fluorescence would be quenched in the first place and subsequently recovered via the addition of analyte. Surfactant-free copper nanoclusters were exploited as a turn-on probe for quantification of vitamin C [55]. In the first step, the fluorescence was quenched by the formation of Fe-Cu NCs conjugate through a static quenching mechanism. On account of the strong reducing property of vitamin $\mathrm{C}$, the $\mathrm{Fe}^{3+}$ were converted into $\mathrm{Fe}^{2+}$, which consequently resulted in the dissociation of Fe-Cu NCs conjugate and restored fluorescent intensity.

As AIE has become an enticing topic in recent years, many turn-on sensors were developed inspired by this phenomenon. Boonmee et al. established a fluorescent assay based on $\mathrm{Al}^{3+}$ induced AIE of cysteamine-capped $\mathrm{Cu} \mathrm{NCs} \mathrm{[56].} \mathrm{Al}^{3+}$ could interact with the amino groups on the surface of $\mathrm{Cu}$ NCs, causing aggregation of nanoclusters. The detection was realized through fluorescence enhancement triggered by the aggregation. Similar strategy was also applied in detection of $\mathrm{S}^{2-}$ and $\mathrm{Pb}^{2+}[10,57]$. Specially, some studies directly utilized the formation of copper nanoclusters as a selective $\mathrm{Cu}^{2+}$ turn-on sensing method [38,58]. Apart from AIE, confinement-induced enhanced emission (CIEE) is also a strategy that frequently used to provide highly fluorescent $\mathrm{Cu} N C$ s with high quantum yield $[36,59,60]$. The improved fluorescence property was achieved by restricting the free movement of fluorescent molecules with the host materials [61]. Yang et al. constructed a turn-on sensing method for bio-enzyme based on CIEE with ultra-high sensitivity [62]. In this work, a fluorescent composite GS-Cu NCs and LDH (GS-Cu NCs/LDH) was fabricated on the basis of surface confinement effect, affording excellent quantum yield, improved stability and long fluorescence lifetime. The surface confinement effect of this material was firstly inhibited by hyaluronic acid (HA). In the presence of hyaluronidase (HAase), the HA would be hydrolyzed, leading to the recovery of fluorescence enhancement. In this way, a fluorescent assay for cancer biomarker HAase was successfully developed.

\subsubsection{Ratiometric Analysis}

Ratiometric fluorescence sensors have also attracted increasing research interest since it exhibits dominant advantages in accuracy, sensitivity and stability. In a ratiometric sensing approach, the detection is achieved by the intensity ratio of dual-emission peaks, which could eliminate the interference of environment and probe concentrations by selfcalibration. A CuNC@AF660 sensor was fabricated for ratiometric sensing of calcium ions. The fluorescence intensity of $\mathrm{Cu}$ NCs emission peak was enhanced gradually with the increase in $\mathrm{Ca}^{2+}$ concentration through ion-induced AIE mechanism. The Alex Fluor 660 NHS ester fabricated on Cu NCs provides the inner-reference signal.

In some ratiometric sensing systems, one emission peak is quenched while the other is enhanced in the presence of analytes. In these cases, the underlying mechanism is usually ascribed to Förster resonance energy transfer (FRET). A probe based on aptamer-modified Copper @ Gold nanoclusters (apt-Cu@Au NCs) was designed for ratiometric detection of $\mathrm{Hg}^{2+}$ [63]. The mercury ions were captured by T-rich nucleic acid single strands on the 
surface of nanoclusters. The formation of $\mathrm{T}-\mathrm{Hg}^{2+}-\mathrm{T}$ structure led to aggregation between the two fluorophores and affected the fluorescence intensity via FRET between Au NCs and $\mathrm{Cu}$ NCs.

\section{Sensing Applications Based on Cu NCs}

\subsection{Pesticides as Target Analytes}

Pesticide residues have been widespread in the environment due to the excessive use of pesticides in agricultural production and horticulture [64-66]. It has been found that even trace amounts of highly toxic pollutants could greatly threaten the ecosystem and human health.

In this section, we mainly highlight the $\mathrm{Cu}$ NCs-based detection systems targeting common pesticides (Table 1), e.g., paraoxon, dinotefuran (DNF), o-phenylenediamine (OPD), dithiocarbamates (DTCs), thiram, paraquat, fluazina, nitrofurantoin (NFT). Copper nanocluster was employed in the construction of an enzyme-free electrochemical biosensor toward paraoxon as the model of organophosphates (OP) [12]. The biocompatible nanocomposite Cu NCs@BSA-SWCNT was synthesized by combining bovine serum albumin (BSA) template-capped Cu nanoclusters (Cu NCs@BSA) and single-walled carbon nanotubes (SWCNT), which demonstrated remarkable sensitivity and high electrocatalytic property toward the reduction of paraoxon (Figure 1a). The entrapped $\mathrm{Cu}$ NCs rendered high electrical conductivity and concentrated the redox active centers on the surface of the probe, while the SWCNT further enhanced the electrocatalytic activity along with conductivity of the glassy carbon electrode (GCE) surface. The linear range was $0.5-35 \mu \mathrm{M}$, with a limit of detection of $12.8 \mathrm{nM}$. Moreover, this electrochemical nanocomposite was found to be able to effectively determine paraoxon with satisfied recoveries ranged from $93 \%$ to $104 \%$ in a real water sample. In order to detect and monitor the residues of dinotefuran (DNF), which has been widely used in agriculture, novel sensing probes and platforms based on fluorescent copper nanoclusters have been constructed. Yang et al. [67] established a dual-emission ratiometric fluorescent probe by integrating sulfur-doped carbon quantum dots (S-CQDs) and Cu NCs with mixed fluorescent signals (Figure 1b). The as-developed hybrid (S-CQDs/Cu NCs) was observed to demonstrate desirable sensitivity and selectivity towards DNF with linear range from 10 to $500 \mu \mathrm{M}$. In this nanocomposite, IFE caused the decrease in fluorescent signals of S-CQDs with the addition of $\mathrm{Cu}$ NCs. In the presence of dinitefuran, the IFE between S-CQDs and $\mathrm{Cu}$ NCs would be weakened due to the aggregation of $\mathrm{Cu} \mathrm{NCs}$, leading to the restoration of S-CODs fluorescence. In the case of honey as the real sample, this ratiometric fluorescent S-CQDs/Cu NCs showed good analysis performance for the detection of DNF. Besides, another ratiometric detection system was proposed for o-phenylenediamine (OPD) based on the use of copper nanoclusters [27]. This method achieved signal amplification and ideal sensitivity through the combined influence of the oxidation reaction and FRET effect. With addition of OPD into $\mathrm{Cu} N C s$, the fluorescence intensity of the $\mathrm{Cu}$ NCs at $432 \mathrm{~nm}$ decreased, while the oxidized OPD (oxOPD) showed strong fluorescence at $557 \mathrm{~nm}$. This detection strategy was able to determine OPD in real water samples with an ultralow limit of detection of $0.096 \mathrm{~g} \mathrm{~L}^{-1}$. Furthermore, a rapid and sensitive detection method of dithiocarbamates (DTCs) with dual functionality in fluorescence and colorimetry was established utilizing CTAB -entrapped Cu NCs [68]. Owing to the fluorescence quenching of the $\mathrm{Cu}$ NCs with addition of DTCs, the detection system demonstrated remarkable sensitivity and selectivity toward DTCs with a linear range from 1 to $100 \mathrm{mg} \mathrm{kg}^{-1}$ and a low limit of detection of $0.63 \mathrm{mg} \mathrm{kg}^{-1}$. 


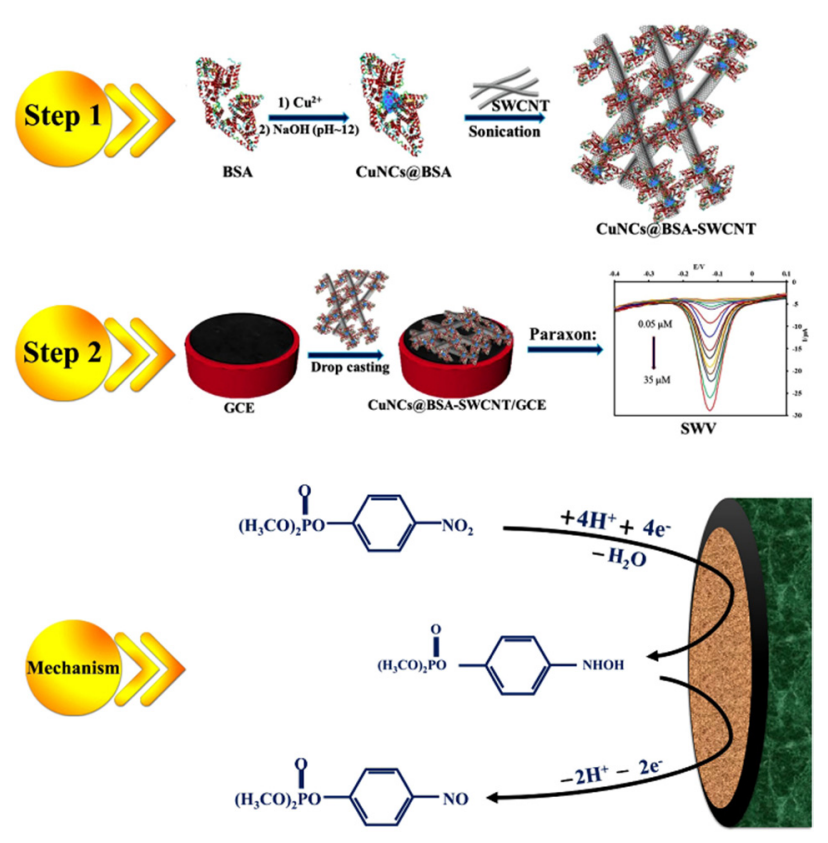

(a)

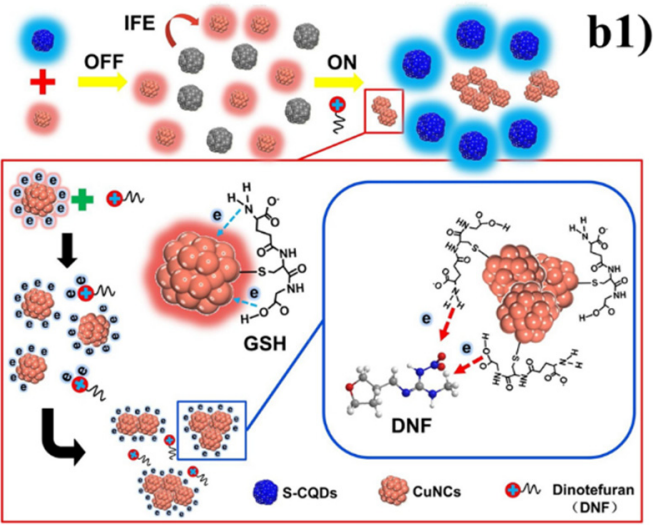

b2)

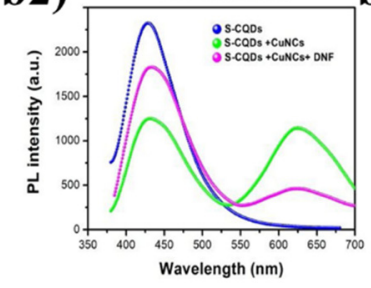

b3)

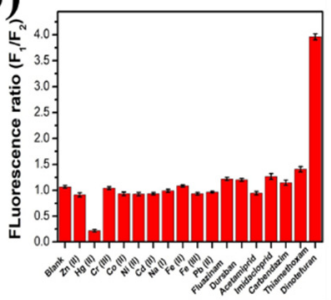

(b)

Figure 1. (a) Schematic representation of biosensor fabrication and suggested mechanism for paraoxon reduction; (b) (b1) The schematic illustration of ratiometric determination of dinotefuran based on S-CQDs/CuNCs probe; (b2) the emission spectra of S-CQDs and S-CQDs/CuNCs with and without the addition of DNF; (b3) selectivity analyses of as-developed ratiometric fluorescent probe mixed various interfering chemicals.

Table 1. List of fluorescent probes based on $\mathrm{Cu}$ NCs for pesticide detection.

\begin{tabular}{|c|c|c|c|c|c|c|c|c|}
\hline No & Analytes & Sensors & $\begin{array}{c}\text { Ex./Em. } \\
\text { Maxima } \\
(\mathrm{nm})\end{array}$ & $\begin{array}{c}\text { Sensing } \\
\text { Mechanism }\end{array}$ & Linear Range & $\begin{array}{l}\text { Limit of } \\
\text { Detection } \\
\text { (LOD) }\end{array}$ & Real Sample & Ref. \\
\hline 1 & Paraoxon & $\begin{array}{l}\text { Cu NCs @ BSA- } \\
\text { SWCNT/GCE }\end{array}$ & $325 / 420$ & $\begin{array}{l}\text { electrochemical } \\
\text { method }\end{array}$ & $\begin{array}{c}0.05-0.5 \mu \mathrm{M} \\
0.5-35 \mu \mathrm{M}\end{array}$ & $12.8 \mathrm{nM}$ & water & [12] \\
\hline 2 & $\begin{array}{l}\text { Thiram } \\
\text { Paraquat }\end{array}$ & Egg white- $\mathrm{Cu}$ NCs & $344 / 600$ & turn off & $\begin{array}{l}0.5-1000 \mu \mathrm{M} \\
0.2-1000 \mu \mathrm{M}\end{array}$ & $70 \mathrm{nM} 49 \mathrm{nM}$ & water & [45] \\
\hline 3 & Metham sodium & CTAB-Cu NCs & $254 / 620$ & $\begin{array}{l}\text { fluorescent } \\
\text { based } \\
\text { colorimetric } \\
\text { method }\end{array}$ & $1-100 \mathrm{mg} \mathrm{kg}^{-1}$ & $0.63 \mathrm{mg} \mathrm{kg}^{-1}$ & $\begin{array}{l}\text { apple, pear } \\
\text { and cherry } \\
\text { tomato }\end{array}$ & [68] \\
\hline 4 & Fluazina & L-Cys-Cu NCs & $365 / 497$ & turn off & $0.05-25 \mu \mathrm{M}$ & $1.4 \mathrm{nM}$ & $\begin{array}{l}\text { pears and } \\
\text { cabbage }\end{array}$ & [33] \\
\hline 5 & $\begin{array}{c}\mathrm{O}^{-} \\
\text {Phenylenediamine }\end{array}$ & GSH-Cu NCs & $334 / 432$ & ratiometric & $0.15-110 \mu \mathrm{g} \mathrm{L}^{-1}$ & $93 \mathrm{ng} \mathrm{L}^{-1}$ & $\begin{array}{l}\text { industry } \\
\text { water }\end{array}$ & [27] \\
\hline 6 & Nitrofurantoin & Adenosine-Cu NCs & $285 / 417$ & turn off & $0.05-4.0 \mu \mathrm{M}$ & $30 \mathrm{nM}$ & lake water & [16] \\
\hline 7 & Dinotefuran & S-CQDs/Cu NCs & $330 / 430$ & ratiometric & $10-500 \mu \mathrm{M}$ & $7.04 \mu \mathrm{M}$ & honey & [67] \\
\hline 8 & $\begin{array}{c}\text { AChE } \\
\text { Methamidophos }\end{array}$ & DNA-Cu/Ag NCs & $480 / 565$ & $\begin{array}{l}\text { turn off } \\
\text { turn on }\end{array}$ & $\frac{0.05-2.0 \mathrm{U} \mathrm{L} \mathrm{L}^{-1}}{-}$ & $\begin{array}{c}0.05 \mathrm{UL}^{-1} \\
0.075 \mathrm{mg} \mathrm{L}^{-1} \\
\left(\mathrm{IC}_{50}\right)\end{array}$ & $\begin{array}{l}\text { water and } \\
\text { vegetable }\end{array}$ & [69] \\
\hline 10 & $\mathrm{AChE}$ & L-His-Cu/Ag NCs & $390 / 485$ & turn off & $\begin{array}{c}0.1-1.0 \mathrm{UL}^{-1} \text { and } \\
1.0-7.0 \mathrm{UL}^{-1}\end{array}$ & $0.03 \mathrm{UL}^{-1}$ & - & [34] \\
\hline 9 & $\mathrm{AChE}$ & PVP-Cu NCs & $370 / 438$ & ratiometric & 2.0-70 $\mathrm{UL}^{-1}$ & $0.56 \mathrm{UL}^{-1}$ & $\begin{array}{l}\text { human } \\
\text { serum } \\
\text { sample }\end{array}$ & [14] \\
\hline 11 & $\mathrm{AChE}$ & PEI-Cu NCs & $365 / 495$ & turn on & $3-200 \mathrm{UL}^{-1}$ & $1.38 \mathrm{UL}^{-1}$ & $\begin{array}{l}\text { human } \\
\text { serum } \\
\text { sample }\end{array}$ & [32] \\
\hline
\end{tabular}

Acetylcholinesterase (AChE) as a key enzyme in relation to Alzheimer's disease (AD) has been a hot detection target for many novel sensing probes based on copper nanoclusters. Due to the intrinsic mechanism of AChE inhibition in the presence of organophosphates, 
these strategies could be extended for pesticide detection. Yang et al. [32] reported the successful establishment of a fluorescence sensing method for the determination of multiple analytes through the induction of UV-light. The polyethyleneimine-protected copper nanoclusters (PEI-Cu NCs) presented strong stability and fluorescence intensity, which was employed in the development a label-free assay for sensitive detection of $\mathrm{Cu}^{2+}$ (Figure 2a). The interaction between $\mathrm{Cu}^{2+}$ with the -SH functional groups in biothiols generated the $\mathrm{RSH}-\mathrm{Cu}^{2+}$ complex, which could trigger the fluorescence recovery of the PEI-Cu NCs. GSH and cysteine (Cy) as two biothiols were consequently detected within a linear range of 1-25 $\mu \mathrm{M}$ and $0.5-25 \mu \mathrm{M}$, respectively. In terms of the AChE activity, thiocholine (TCh) containing -SH group was produced with the hydrolyzation of acetylthiocholine by AChE. TCh interacted with $\mathrm{Cu}^{2+}$ to generate $\mathrm{TCh}-\mathrm{Cu}^{2+}$ complex, which triggered the fluorescence recovery of the PEI-Cu NCs. The response toward AChE was linear ranging from 3-200 $\mathrm{UL}^{-1}$ with a limit of detection of $1.38 \mathrm{UL}^{-1}$. Furthermore, this sensing platform was also employed in the detection of tacrine, a typical inhibitor of $\mathrm{AChE}$ with the $\mathrm{IC}_{50}$ value at $53.4 \mathrm{nM}$. A novel ratiometric florescence probe toward the evaluation of AChE activity was established through incorporating single-atom nanozyme (SAzyme) with the polyvinylpyrrolidone-protected copper nanocluster (PVP-Cu NCs) [14]. The SAzyme was first achieved through conjugating single-atom iron with $\mathrm{N}$-doped porous carbon (Fe-SAs/NC) with peroxidase-like activity (Figure 2b). The obtained Fe-SAs/NC was observed to catalyze oxidation of OPD to 2,3-diaminophenazine (DAP) in the presence of $\mathrm{H}_{2} \mathrm{O}_{2}$. The fluorescent DAP displayed fluorescence emission at $566 \mathrm{~nm}$, while the PVP$\mathrm{Cu}$ NCs exhibited fluorescence emission peak at $438 \mathrm{~nm}$. With the increase in the DAP concentration, the fluorescence intensity of PVP-Cu NCs was found to be quenched. The mechanism behind the quenching effect was confirmed to be FRET between PVP-Cu NCs and DAP through the measurement of fluorescence lifetime. This dual-emission signal system demonstrated high sensitivity toward $\mathrm{AChE}$ activity with a linear range between 2-70 $\mathrm{UL}^{-1}$ and a low limit of detection at $0.56 \mathrm{UL}^{-1}$. Although this exploration proved the effectiveness of SAzymes in AChE analysis, the further investigation into its feasibility in its inhibitor evaluation, especially pesticide residues, is still urgent. Based on the IFE, another sensitive analytical method was proposed based on 5'-Dithiobis-(2-nitrobenzoic acid) (DTNB) and copper/silver nanoclusters [34]. This method exhibited high sensitivity with strong fluorescence within the linear range between $0.1-1.0 \mathrm{U} \mathrm{L}^{-1}$ and with a very low detection limit of $0.03 \mathrm{UL}^{-1}$. Furthermore, the sensor constructed in this work showed distinct color change that could be distinguished by naked eyes, which further improved its feasibility in detecting $\mathrm{AChE}$ from other substance selectively.

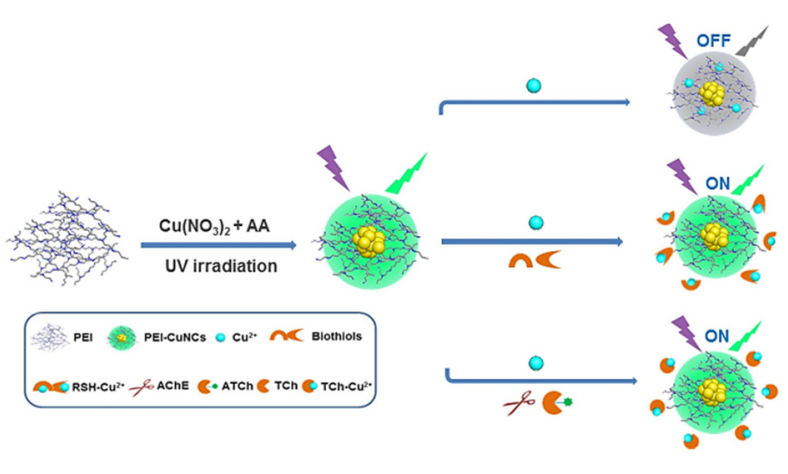

(a)

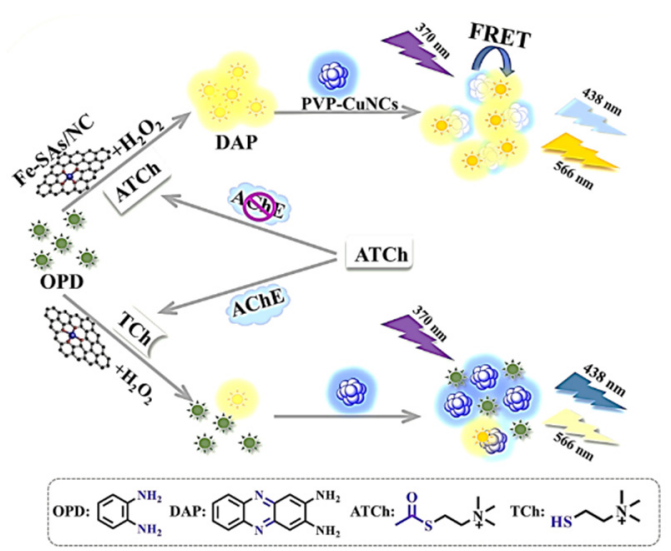

(b)

Figure 2. (a) Schematic illustration of $\mathrm{Cu}^{2+}$-quenched fluorescence turn-on assay for the detection of biothiols and AChE; (b) Schematic illustration of this ratio fluorescent sensing strategy for AChE activity sensing. 


\subsection{Heavy Metals as Target Analytes}

Heavy metals are notorious and hazardous contaminants in environment due to their low degradability, acute toxicity, high bioaccumulation, and other factors. Herein, we summarized nanoprobes based on $\mathrm{Cu}$ NCs for the determination of several representative heavy metal ions including mercury ions $\left(\mathrm{Hg}^{2+}\right)$, lead ions $\left(\mathrm{Pb}^{2+}\right)$, chromate anions $\left(\mathrm{Cr}^{6+}\right)$ and copper ions $\left(\mathrm{Cu}^{2+}\right)$ (Table 2).

\subsubsection{Mercury Ions}

Mercury has been found to be prevalent in the food chain, which poses a huge threat to the health of the ecosystem and humans. The conventional monitoring methods to $\mathrm{Hg}^{2+}$ could barely satisfy the soaring demand of rapid, facile and sensitive determination of this substrate in real samples [70-72]. An analytical method with high signal-to-noise ratio was constructed by regulating the fluorescence of copper nanoclusters through engineering the reticular poly(T) DNA template [40]. The fluorescence intensity of as-designed copper-based nanoclusters was observed to be enhanced to a great extent by using this DNA template with its unique structure and its resistance towards enzyme digestion. This novel DNA-templated nanomaterial exhibited excellent sensitivity and selectivity toward mercury ions with a desirably linear range from $50 \mathrm{pM}$ to $500 \mu \mathrm{M}$ and a remarkably low limit of detection at $16 \mathrm{pM}$ (Figure 3a). Meanwhile, owning to the interplay between $\mathrm{Hg}^{2+}$ and GSH, this sensory probe could also be employed to detect the inhibition of GSH by $\mathrm{Hg}^{2+}$ and thus to determine the GSH in real biological samples. In the real sample analysis, this biosensor was found to be a reliable and feasible analytical method. An instant-response and facile analysis platform targeting $\mathrm{Hg}^{2+}$ and $\mathrm{S}^{2-}$ ions was established through incorporating copper nanoclusters with 1 -Thio- $\beta$-Dglucose as a capping ligand via ultrasonication, the synthesis of which could be completed in as fast as one minute [73]. As shown in Figure 3b, the as-synthesized TG-Cu NCs demonstrated the emission maximum at $430 \mathrm{~nm}$, and through fluorescence quenching, this probe is able to detect $\mathrm{Hg}^{2+}$ and $\mathrm{S}^{2-}$ ions with very low detection limits at 1.7 and $1.02 \mathrm{nM}$, respectively. This on-site detection and monitoring of the target analytes in real samples (e.g., tap, river and pond water) could be achieved easily with the developed cheap smartphone-aided and paperbased kit. Shi et al. [63] developed a ratiometric sensing strategy toward mercury ions by modifying copper nanoclusters @ gold nanoclusters via aptamer (apt-Cu@Au NCs). The changes in the fluorescence of this novel probe is attributed to the FRET strategy, which was achieved through the thymidine- $\mathrm{Hg}$-thymidine $(\mathrm{T}-\mathrm{Hg}-\mathrm{T})$ structure generated by addition of $\mathrm{Hg}^{2+}$ into the solution containing apt-Cu@Au NCs. $\mathrm{Hg}^{2+}$ ions could be detected with a range from 0.1 to $9.0 \mu \mathrm{M}$ with the detection limit of $4.92 \mathrm{nM}$ (Figure 4a). Meanwhile, to improve the feasibility, practicality, cost-effectiveness and the user-friendliness of this sensor, a smartphone-aided visualization method based on the fluorescent microfluidic chip was proposed to enable the facile and on-site determination of the target analytes. This sensing platform exhibited good performance in real samples with recovery rate at $101.83-114.00 \%$. In another $\mathrm{Hg}^{2+}$ sensor, $\mathrm{Cu}$ NCs were assembled with polymers with multi-thiol groups as templates ( $\mathrm{Cu}$ NCs@P-8B) through the simple one-pot approach [74]. This nanohybrid demonstrated satisfactory water stability, high sensitivity and responsiveness to $\mathrm{pH}$ and temperature, with a linear range between 10-100 $\mu \mathrm{M}$ and a limit of detection of $10 \mu \mathrm{M}$. Its performance in the real sample test with human urine indicated its potential in practical applications. 


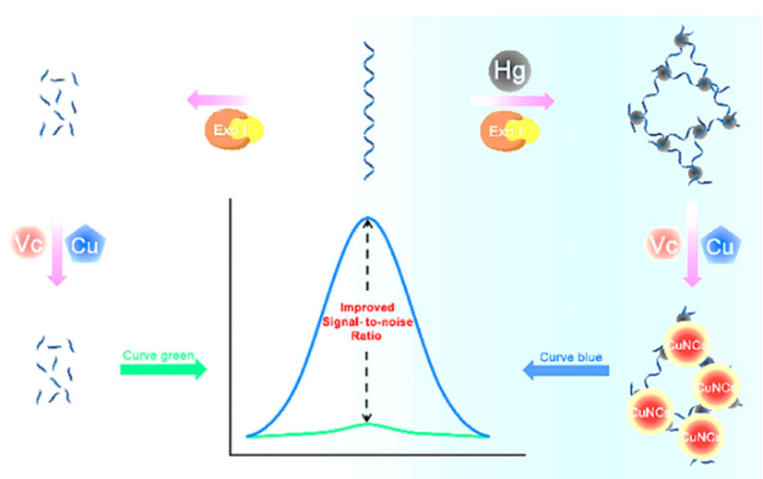

(a)

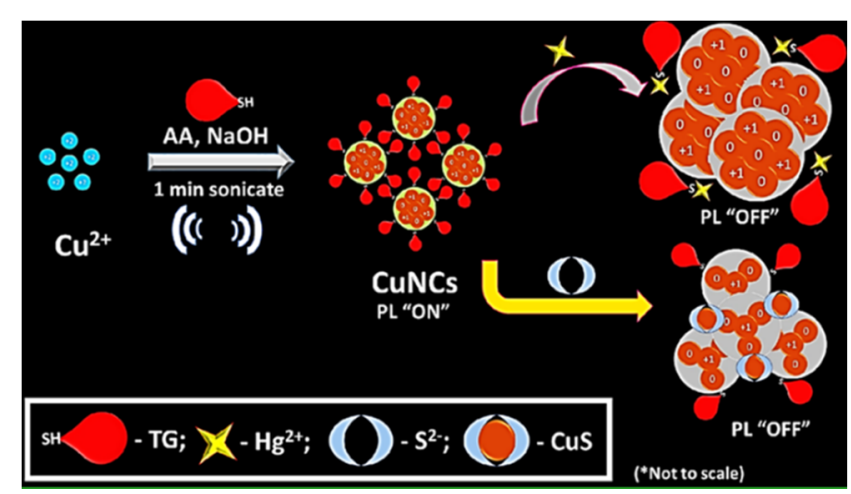

(b)

Figure 3. (a) Schematic Illustration of $\mathrm{Hg}^{2+}$ Quantification Based on Fluorescence Regulation of CuNCs via DNA Template Manipulation; (b) Schematic representation for the possible mechanism of $\mathrm{Hg}^{2+}$ and $\mathrm{S}^{2-}$ detection using TG-CuNCs.

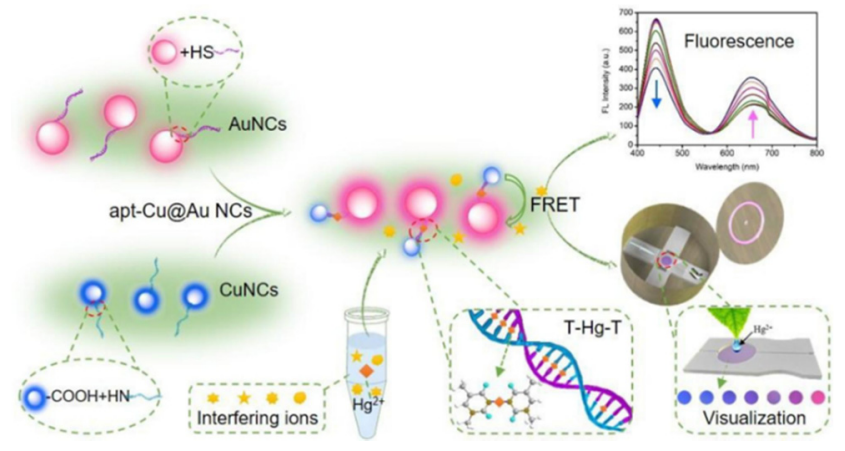

(a)

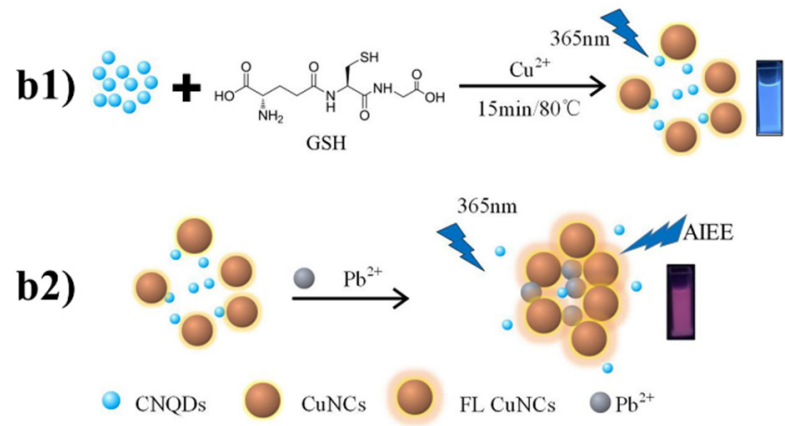

(b)

Figure 4. (a) Schematic of apt-Cu@Au NCs aptasensor for $\mathrm{Hg}^{2+}$ ions detection; (b) (b1) Schematic of the preparation of CuNCs-CNQDs nanohybrid; (b2) Schematic for the $\mathrm{Pb}^{2+}$ detection assay.

\subsubsection{Lead Ions}

Similarly, numerous novel probes have also been developed and investigated to monitor lead ions $\left(\mathrm{Pb}^{2+}\right)$ in the environment and in the drinking water system, as lead is highly biotoxic and threatens the health of children, in particular. Intake of extremely low levels of lead can cause cardiovascular, nervous, and reproductive diseases [75,76]. Based on the nanocomposite of copper nanoclusters and carbon quantum dots ( $\mathrm{Cu}$ NCsCNQDs) blended in nitrogen, a novel ratiometric fluorescence determination method was reported to detect and analyze the trace amount of hypertoxic lead ions in a popular aquatic product porphyra [77]. As illustrated in Figure $4 \mathrm{~b}$, the fluorescence emission of the $\mathrm{Cu}$ NCs-CNQDs was observed to peak at $468 \mathrm{~nm}$ and $632 \mathrm{~nm}$. The fluorescence of this $\mathrm{Cu}$ NCs was considerably enhanced when $\mathrm{Pb}^{2+}$ was added into the solution owing to the aggregation-induced emission enhancement (AIEE) between $\mathrm{Pb}^{2+}$ and $\mathrm{Cu}$ NCs. Meanwhile, the fluorescence of CNQDs remained the same, which could be taken as the self-calibration signal, and the $\mathrm{Cu}$ NCs-CNQDs demonstrated remarkable sensitivity and selectivity toward $\mathrm{Pb}^{2+}$ in porphyra ranging from $0.010 \mathrm{mg} / \mathrm{L}$ to $2.5 \mathrm{mg} / \mathrm{L}$, with a low detection limit of $0.0031 \mathrm{mgL}^{-1}$. Goswami and co-workers [18] proposed a BSAcapped $\mathrm{Cu}$ quantum clusters (CuQC@BSA) as the probe targeting $\mathrm{Pb}^{2+}$. The as-developed nanocomposite was highly sensitive toward $\mathrm{Pb}^{2+}$, which is attributed to the fluorescence quenching effect in ultra-low concentration of hydrogen peroxide at $200 \mathrm{ppm}$. It also performed well, even in the presence of interference from other metal ions. In another work, GSH-stabilized Cu NCs (GSH-Cu NCs) was fabricated successfully via the simple sonochemical synthesis method [39]. Based on the fluorescence quenching mechanism, this hybrid showed excellent performance in the label-free detection of $\mathrm{Pb}^{2+}$ with a linear range between 1 and $160 \mathrm{nM}$ and a detection limit as low as $1.0 \mathrm{nM}$. 


\subsubsection{Chromate Anions}

Chromium ( $\mathrm{Cr}(\mathrm{VI})$ ) has been extensively used in the modern industrial production and has also been a common contaminant in the environment. Considering its hugely harmful effect on human health, various analytical methods for the detection of chromium have been designed and, similar to other heavy metal contaminants, many novel sensors based on metal nanoclusters for $\mathrm{Cr}$ (VI) have been constructed. Bai and coworkers [78] proposed a ratiometric fluorescent probe for the convenient and effective detection of $\mathrm{Cr}_{2} \mathrm{O}_{7}{ }^{2-}$ or $\mathrm{Cd}^{2+}$ by integrating GSH-based carbon dots with copper nanoclusters. As shown in Figure 5a, the carbon dots-stabilized copper nanoclusters (GSH@CDs-Cu NCs) exhibited two obvious emission peaks at $450 \mathrm{~nm}$ and $750 \mathrm{~nm}$, respectively. Owing to fluorescence quenching or enhancement of the nanohybrid, the GSH@CDs-Cu NCs showed good sensitivity and selectivity toward $\mathrm{Cr}_{2} \mathrm{O}_{7}{ }^{2-}$ with a linear range from 2 to $40 \mu \mathrm{mol} \mathrm{L}{ }^{-1}$ and a detection limit of $0.9 \mu \mathrm{mol} \mathrm{L}^{-1}$, and $\mathrm{Cd}^{2+}$ with a linear range from 0 to $20 \mu \mathrm{mol} \mathrm{L}^{-1}$ and a detection limit of $0.6 \mu \mathrm{mol} \mathrm{L}{ }^{-1}$. In addition, successful application of the fluorescence test strips was achieved in the rapid detection of $\mathrm{Cr}_{2} \mathrm{O}_{7}{ }^{2-}$ ions with distinct fluorescent color changes from pink to purple under UV light. In the test of real samples, the recovery rates of the target analytes in various water samples were in the range from $102 \%$ to $109 \%$ with the relative standard deviations (RSD) smaller than $4.5 \%$. And the recovery rates of the target analytes ranged from $97 \%$ to $108 \%$ with the RSD smaller than $3.5 \%$. Through the one-pot galvanic reduction approach, gold-copper nanoclusters capped by cysteamine (CA-AuCu NCs) were prepared for the detection of chromium(VI) and dopamine, the levels of which are critical to the development of severe diseases [23]. The distinct optical properties of this probe made it an ideal candidate in the determination of the target analytes in real samples, such as tap water, lake water, sea water and human urine. In particular, this switch-off probe was responsive in the linear range of $0.2-100 \mu \mathrm{m}$ for $\mathrm{Cr}$ (VI) and with a detection limit of $80 \mathrm{nM}$.

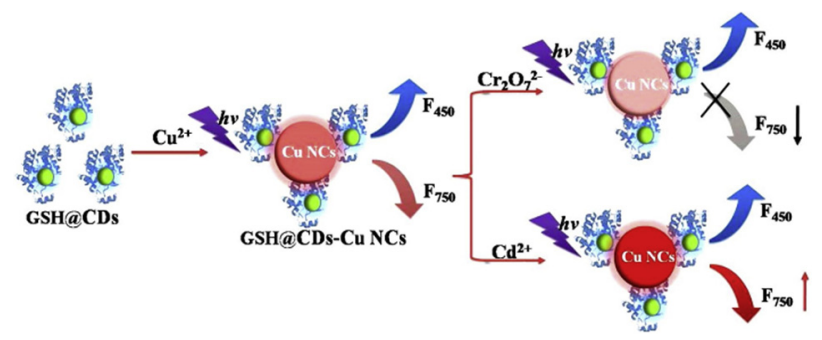

(a)

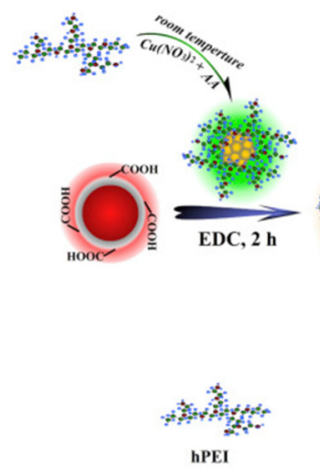

EI

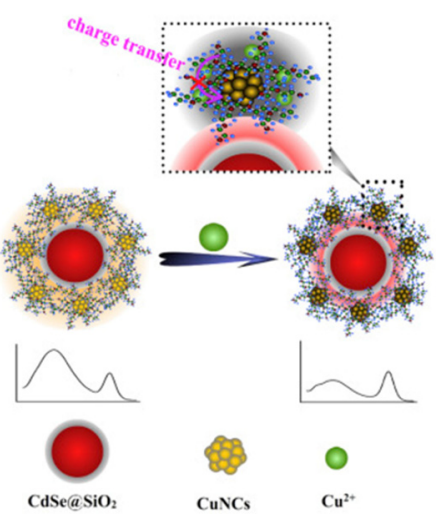

(b)

Figure 5. (a) Schematic illustration of the preparation of GSH@CDs-Cu NCs and the application in the detection of $\mathrm{Cr}_{2} \mathrm{O}_{7}{ }^{2-}$ and $\mathrm{Cd}^{2+}$ ions; (b) Schematic illustration of the preparation of dual-emission ratiometric fluorescence probe and its sensing mechanism to $\mathrm{Cu}^{2+}$ ions.

\subsubsection{Copper Ions}

The prevalence of copper ion residues in the food and in the environment is another looming danger due to damage to the human liver and the nervous system caused by excessive $\mathrm{Cu}^{2+}$. Typically, Alzheimer's disease (AD), as a common neurodegenerative disease, might be caused by excessive accumulation of copper ion and corresponding oxidative stress [79,80]. Hyperbranched polyethyleneimine-protected copper nanoclusters (hPEI-Cu NCs) were integrated with the silica-coated CdSe quantum dots (QDs) to obtain a novel ratiometric and visual analytical probe toward copper ions through the simple and green one-pot chemical reduction method at room temperature [81]. This QDs@Cu NCs probe exhibited high sensitivity and visual detection capability toward $\mathrm{Cu}^{2+}$, which could be attributed to the self-calibration function of the dual-emission fluorescence signals 
inherent in the ratio-based fluorescence probe. The fluorescence of hPEI-Cu NCs was quenched due to the interaction of its amine groups with $\mathrm{Cu}^{2+}$, while the fluorescence intensity of QDs remained unchanged, and the distinct color changes could be easily observed by the naked eye under the UV-light. The linear range of the probe in $\mathrm{Cu}^{2+}$ concentrations was, approximately, from $22 \mathrm{nM}$ to $8.8 \mu \mathrm{M}$, with an estimated detection limit of $8.9 \mathrm{nM}$ (Figure $5 \mathrm{~b}$ ). When applied in the real water samples with different concentrations of $\mathrm{Cu}^{2+}$, the as-synthesized probe exhibited satisfactory recovery.

Table 2. List of fluorescent probes based on Cu NCs for heavy metal detection.

\begin{tabular}{|c|c|c|c|c|c|c|c|c|}
\hline No & Analytes & Sensors & $\begin{array}{c}\text { Ex./Em. } \\
\text { Maxima (nm) }\end{array}$ & $\begin{array}{c}\text { Sensing } \\
\text { Mechanism }\end{array}$ & Linear Range & $\begin{array}{l}\text { Limit of } \\
\text { Detection } \\
\text { (LOD) }\end{array}$ & Real Sample & Ref. \\
\hline 1 & $\mathrm{Hg}^{2+}$ & Cu NCs@P-8B & $400 / 535$ & turn off & $10-100 \mu \mathrm{M}$ & $10 \mu \mathrm{M}$ & $\begin{array}{l}\text { aqueous } \\
\text { solution }\end{array}$ & [74] \\
\hline 2 & $\mathrm{Hg}^{2+}$ & Curcuminoids-Cu NCs & $350 / 440$ & turn off & $0.5 \mathrm{nM}-25 \mu \mathrm{M}$ & $0.12 \mathrm{nM}$ & water & [54] \\
\hline 3 & $\mathrm{Hg}^{2+}$ & $\mathrm{Cu} \mathrm{NCs}$ & $340 / 560$ & turn off & $2-40 \mu \mathrm{M}$ & $23 \mathrm{nM}$ & $\begin{array}{c}\text { water } \\
\text { human urine }\end{array}$ & [72] \\
\hline 4 & $\mathrm{Hg}^{2+}+$ & Trypsin-Cu NCs & $360 / 567$ & turn off & $0.1-100 \mu \mathrm{M}$ & $30 \mathrm{nM}$ & $\begin{array}{l}\text { and serum } \\
\text { samples }\end{array}$ & [28] \\
\hline 5 & $\mathrm{Hg}^{2+}$ & TdT-INAA-DNA-Cu NCs & $343 / 600$ & turn off & $0.2-500 \mathrm{nM}$ & $76 \mathrm{pM}$ & $\begin{array}{l}\text { environmental } \\
\text { water }\end{array}$ & [41] \\
\hline 6 & $\mathrm{Hg}^{2+}$ & GSH-Cu NCs & $360 / 445$ & turn off & $10 \mathrm{nM}-10 \mu \mathrm{M}$ & $3.3 \mathrm{nM}$ & $\begin{array}{l}\text { water and } \\
\text { rice }\end{array}$ & [13] \\
\hline 7 & $\mathrm{Hg}^{2+}$ & poly(30T) DNA-Cu NCs & $340 / 650$ & turn on & $\begin{array}{l}50 \mathrm{pM}-2.5 \mu \mathrm{M} \\
\text { and } 2.5-500 \mu \mathrm{M}\end{array}$ & $16 \mathrm{pM}$ & lake water & [40] \\
\hline 8 & $\mathrm{Hg}^{2+}$ & $\begin{array}{l}\text { DTT-Cu NCs/CNNS } \\
\text { nanocomposite }\end{array}$ & $395 / 615$ & $\begin{array}{l}\text { electrochem- } \\
\text { iluminescence }\end{array}$ & $0.05-10 \mathrm{nM}$ & $0.01 \mathrm{nM}$ & $\begin{array}{l}\text { lake and tap } \\
\text { water }\end{array}$ & [71] \\
\hline 9 & $\mathrm{Hg}^{2+}$ & Metallothionein-Cu NCs & - & UV-VIS & $\begin{array}{c}97 \mathrm{~nm}-2.3 \mu \mathrm{M} \\
\text { and } 3.1-15.6 \mu \mathrm{M}\end{array}$ & $43.8 \mathrm{nM}$ & $\begin{array}{l}\text { environmental } \\
\text { water }\end{array}$ & [82] \\
\hline 10 & $\mathrm{Hg}^{2+}$ & GSH-Cu NCs & $375 / 440$ & turn off & $0.04-60 \mu \mathrm{M}$ & $22 \mathrm{nM}$ & water & [26] \\
\hline 11 & $\mathrm{Hg}^{2+}$ & $\begin{array}{c}\text { Cytosine rich- } \\
\text { ssDNA-Cu/Ag NCs }\end{array}$ & $470 / 550$ & turn off & $40-550 \mathrm{nM}$ & $2.4 \mathrm{nM}$ & $\begin{array}{l}\text { lake and tap } \\
\text { water }\end{array}$ & [31] \\
\hline 12 & $\mathrm{Hg}^{2+}$ & apt-Cu@Au NCs & $470 / 656$ & ratiometric & $0.1-9.0 \mu \mathrm{M}$ & $4.92 \mathrm{nM}$ & porphyra & [63] \\
\hline 13 & $\mathrm{Hg}^{2+}$ & $\begin{array}{l}\text { 4-chlorothiophenol- } \\
\text { Cu NCs }\end{array}$ & $330 / 605$ & turn off & 1-500 nM & $0.3 \mathrm{nM}$ & $\begin{array}{l}\text { environmental } \\
\text { water }\end{array}$ & [83] \\
\hline 14 & $\mathrm{Hg}^{2+}$ & BSA-Cu NCs & $320 / 420$ & turn off & $0.01 \mathrm{nM}-10 \mu \mathrm{M}$ & $4.7 \mathrm{pM}$ & water & [19] \\
\hline 15 & $\mathrm{Hg}^{2+}$ & BSA-Cu NCs & $395 / 645$ & turn off & 20-1000 nM & $0.2 \mathrm{nM}$ & - & [84] \\
\hline 16 & $\mathrm{Hg}^{2+}$ & L-Cys-Cu NCs & $375 / 480$ & turn off & $0.1-1000 \mu \mathrm{M}$ & $24 \mathrm{nM}$ & $\begin{array}{l}\text { human urine } \\
\text { sample }\end{array}$ & [17] \\
\hline 17 & $\mathrm{Hg}^{2+}$ & dsDNA-Cu NCs & $570 / 595$ & turn off & $0.04-8 \mathrm{nM}$ & $4 \mathrm{pM}$ & water & [70] \\
\hline 18 & $\mathrm{Hg}^{2+}$ & $\mathrm{Ag} / \mathrm{Cu} \mathrm{NCs}$ & colorimetric & turn on & $0.1-700 \mathrm{nM}$ & $0.05 \mathrm{nM}$ & $\begin{array}{l}\text { aqueous } \\
\text { sample }\end{array}$ & [85] \\
\hline 19 & $\mathrm{Hg}^{2+}$ & CDs-CuNCs & $345 / 430,647$ & ratiometric & 0-4000 nM & $0.31 \mathrm{nM}$ & $\begin{array}{l}\text { Tap, lake } \\
\text { water }\end{array}$ & [86] \\
\hline 20 & $\mathrm{Hg}^{2+}$ & $\begin{array}{l}\text { BSA-Cu NCs/ } \\
\text { BSA-Au NCs }\end{array}$ & $365 / 398,616$ & ratiometric & $\begin{array}{c}0.06-1 \mu \mathrm{M} \text { and } \\
1-4 \mu \mathrm{M}\end{array}$ & $19.4 \mathrm{nM}$ & $\begin{array}{l}\text { Tap, mineral, } \\
\text { lake water }\end{array}$ & [87] \\
\hline 21 & $\mathrm{~Pb}^{2+}$ & BSA-Cu NCs & $\begin{array}{c}324 / 401 \\
\text { (fluorescent); } \\
\text { 324/396 (light } \\
\text { scattering) }\end{array}$ & $\begin{array}{l}\text { turn off; } \\
\text { turn on }\end{array}$ & $\begin{array}{l}\text { 30-180 nM; } \\
\text { 3-21 nM }\end{array}$ & $\begin{array}{l}10 \mathrm{nM} ; \\
1 \mathrm{nM}\end{array}$ & $\begin{array}{l}\text { environmental } \\
\text { water }\end{array}$ & [88] \\
\hline 22 & $\mathrm{~Pb}^{2+}$ & BSA-Cu NCs & $325 / 410$ & turn off & 0-200 ppm & - & - & [18] \\
\hline 23 & $\mathrm{~Pb}^{2+}$ & GSH-Cu NCs & $360 / 607$ & turn on & $200-700 \mu \mathrm{M}$ & $106 \mu \mathrm{M}$ & water & [57] \\
\hline 24 & $\mathrm{~Pb}^{2+}$ & $\mathrm{Cu}$ NCs-CNQDs & $365 / 468,632$ & ratiometric & $0.01-2.5 \mathrm{mg} \mathrm{L}^{-1}$ & $0.0031 \mathrm{mg} \mathrm{L}^{-1}$ & porphyra & [77] \\
\hline 25 & $\mathrm{~Pb}^{2+}$ & Metallothionein-Cu NCs & - & UV-VIS & $0.7-96 \mu \mathrm{M}$ & $142 \mathrm{nM}$ & $\begin{array}{l}\text { environmental } \\
\text { water }\end{array}$ & [82] \\
\hline 26 & $\mathrm{~Pb}^{2+}$ & dsDNA-Cu NCs & $340 / 605$ & turn off & $0-150 \mathrm{pM}$ & $5.2 \mathrm{pM}$ & tap water & [43] \\
\hline 27 & $\mathrm{~Pb}^{2+}$ & GSH-Cu NCs & $420 / 606$ & turn off & $1-160 \mathrm{nM}$ & $1 \mathrm{nM}$ & - & [39] \\
\hline 28 & $\mathrm{~Pb}^{2+}$ & $\mathrm{Cu}$ NASs & $340 / 590$ & turn off & $2-100 \mathrm{nM}$ & $0.75 \mathrm{nM}$ & $\begin{array}{l}\text { aqueous } \\
\text { sample } \\
\text { tap water }\end{array}$ & [89] \\
\hline 29 & $\mathrm{Cr}_{2} \mathrm{O}_{7}^{2-}$ & GSH@CDs-Cu NCs & $360 / 450,750$ & ratiometric & $0-20 \mu \mathrm{M}$ & $0.9 \mu \mathrm{M}$ & $\begin{array}{l}\text { spring water } \\
\text { samples and } \\
\text { human urine }\end{array}$ & [78] \\
\hline 30 & $\mathrm{Cr}(\mathrm{VI})$ & $\begin{array}{c}\text { DAMP-Cu NCs } \\
\text { Thiosalicylic }\end{array}$ & $357 / 428$ & turn off & $0-150 \mu \mathrm{M}$ & $8.5 \mu \mathrm{M}$ & water & [24] \\
\hline 31 & $\mathrm{Cr}(\mathrm{VI})$ & $\begin{array}{c}\text { acid/Cysteamine- } \\
\text { Cu NCs }\end{array}$ & $355 / 411$ & turn off & $0.1-1000 \mu \mathrm{M}$ & $30 \mathrm{nM}$ & water & [21] \\
\hline
\end{tabular}


Table 2. Cont

\begin{tabular}{|c|c|c|c|c|c|c|c|c|}
\hline No & Analytes & Sensors & $\begin{array}{c}\text { Ex./Em. } \\
\text { Maxima (nm) }\end{array}$ & $\begin{array}{c}\text { Sensing } \\
\text { Mechanism }\end{array}$ & Linear Range & $\begin{array}{c}\text { Limit of } \\
\text { Detection } \\
\text { (LOD) }\end{array}$ & Real Sample & Ref. \\
\hline 32 & $\mathrm{Cr}(\mathrm{VI})$ & Cysteamine-Au/Cu NCs & $350 / 436$ & turn off & $0.2-100 \mu \mathrm{M}$ & $80 \mathrm{nM}$ & $\begin{array}{l}\text { water and } \\
\text { human urine } \\
\text { sample }\end{array}$ & [23] \\
\hline 33 & $\mathrm{Cr}(\mathrm{VI})$ & Cu NCs@TA & $360 / 430$ & turn off & $0.03-60 \mu \mathrm{M}$ & $5 \mathrm{nM}$ & $\begin{array}{c}\text { water } \\
\text { sample }\end{array}$ & [90] \\
\hline 34 & $\mathrm{Cu}^{2+}$ & D-Penicillamine -Cu NCs & $391 / 673$ & turn on & 0.95-6.35 ppm & $0.3 \mathrm{ppm}$ & tap water & [91] \\
\hline 35 & $\mathrm{Cu}^{2+}$ & $\begin{array}{c}\text { CdSe QDs@ } \\
\text { hPEI-Cu NCs }\end{array}$ & $380 / 495,625$ & ratiometric & $0.022-8.8 \mu \mathrm{M}$ & $8.9 \mathrm{nM}$ & river water & [81] \\
\hline 36 & $\mathrm{Cu}^{2+}$ & GSH- Cu NCs & $330 / 615$ & turn on & $0.25-10 \mu \mathrm{M}$ & $170 \mathrm{nM}$ & chalcocite & [38] \\
\hline 37 & $\mathrm{Cu}^{2+}$ & DNA-Cu/Ag NCs & $480 / 576$ & turn on & 5-200 nM & $2.7 \mathrm{nM}$ & $\begin{array}{c}\text { soil and } \\
\text { pond water }\end{array}$ & [42] \\
\hline 38 & $\mathrm{Cu}^{2+}$ & Cytidine-Cu NCs & $300 / 380$ & turn on & $0.05-2.0 \mu \mathrm{M}$ & $32 \mathrm{nM}$ & lake water & [58] \\
\hline 39 & $\mathrm{Cu}^{2+}$ & BSA-Cu NCs & $340 / 420$ & turn off & $0.02-34 \mu \mathrm{M}$ & $1 \mathrm{nM}$ & tap water & [20] \\
\hline 40 & $\mathrm{Cu}^{2+}$ & $\begin{array}{l}\text { BSA-Cu NCs / } \\
\text { BSA-Au NCs }\end{array}$ & $365 / 398,616$ & ratiometric & $\begin{array}{c}0.1-1 \mu \mathrm{M} \text { and } 1-5 \\
\mu \mathrm{M}\end{array}$ & $23.4 \mathrm{nM}$ & $\begin{array}{l}\text { Tap, mineral, } \\
\text { lake water }\end{array}$ & [87] \\
\hline
\end{tabular}

\subsection{Sulfide as Target Analytes}

Another main category of environmental pollutants is sulfide ions, which are also byproducts of massive industrial development. Their wide distribution in different formats (i.e., $\mathrm{H}_{2} \mathrm{~S}, \mathrm{HS}^{-}$and $\mathrm{S}^{2-}$ ) in nature makes them a latent crisis, threatening human health. $\mathrm{Cu}$ NCs have also been extensively utilized to determine sulfide ions (Table 3). A "turn-on" determination strategy toward sulfide ion $\left(\mathrm{S}^{2-}\right)$ was developed based on fluorescent copper nanoclusters with natural silk fibroin (SF) protein as template (SF@Cu NCs), which was synthesized via utilizing the environmental friendly and user-friendly one-pot method [10]. With the addition of $\mathrm{S}^{2-}$ ions into the aqueous solutions, the fluorescence intensity of the probe was observed to be increased, due to the inherent feature of aggregation/assemblyinduced emission enhancement (AIEE). The $S^{2-}$ could induce the self-assembly of copper nanoclusters into large rod-shape nanoparticles. This SF@Cu NCs nanohybrid demonstrated good sensitivity and selectivity toward $\mathrm{S}^{2-}$ with a linear range of $5.0 \mu \mathrm{M}-110.0 \mu \mathrm{M}$ and the limit of detection at $0.286 \mu \mathrm{M}$. In the real sample test, this analytical approach was found to be powerful in determining the sulfide ions at different concentrations with a satisfactory recovery rate of 95.6-101.6\%. Another sensing platform for the determination of sulfide ions was reported. The main component of this approach was synthesized through modifying copper nanoclusters by 3-mercaptopropionic acid and with AIE induced by $\mathrm{Cu}^{2+}\left(\mathrm{Cu}^{2+} @ \mathrm{MPA}-\mathrm{Cu} \mathrm{NCs}\right)$ [92]. The preparation process of this luminescence probe was easy-to-operate and facile. The probe exhibited good linear detection of $\mathrm{S}^{2-}$ in the range from 0 to $600 \mu \mathrm{M}$, with a detection limit of $26.3 \mathrm{nM}$ (Figure 6). In the quantitative detection of $\mathrm{S}^{2-}$, the $\mathrm{Cu}^{2+} @ \mathrm{MPA}-\mathrm{Cu}$ NCs sensor presented high selectivity and good accuracy in the simulated real environment, with recovery rates ranging from $92.5 \%$ to $104.5 \%$ and RSD less than $4 \%$. Ratio-based sensing systems for the monitoring of sulfide ions have also been established based on all $\mathrm{Cu}$ NCs (G-R-Cu NCs) [93]. The fluorescent probe was obtained through rapid and simple synthesis procedure and exhibited remarkable selectivity and sensitivity in the real sample.

Table 3. List of fluorescent probes based on $\mathrm{Cu}$ NCs for sulfide anions detection.

\begin{tabular}{|c|c|c|c|c|c|c|c|c|}
\hline No & Analytes & Sensors & $\begin{array}{c}\text { Ex./Em. } \\
\text { Maxima }(\mathrm{nm})\end{array}$ & $\begin{array}{c}\text { Sensing } \\
\text { Mechanism }\end{array}$ & Linear Range & $\begin{array}{c}\text { Limit of } \\
\text { Detection (LOD) }\end{array}$ & Real Sample & Ref. \\
\hline 1 & $\mathrm{H}_{2} \mathrm{~S}$ & PSS-PA-Cu NCs & $325 / 655$ & turn-off & $2-10 \mu \mathrm{M}$ & $650 \mathrm{nM}$ & spring water & [94] \\
\hline 2 & $\mathrm{~S}^{2-}$ & G-R-Cu NCs & $400 / 490,610$ & ratiometric & $\begin{array}{c}0.1-10 \mu \mathrm{M} \text { and } \\
0.1-10 \mathrm{mM}\end{array}$ & $100 \mathrm{nM}$ & chicken blood & [93] \\
\hline 3 & $\mathrm{~S}^{2-}$ & TA-Cu NCs & $360 / 441$ & $\begin{array}{c}\text { turn-off } \\
\text { colorimetric }\end{array}$ & $\begin{array}{c}0.7-80 \mu \mathrm{M} \\
6-130 \mu \mathrm{M}\end{array}$ & $\begin{array}{l}0.1 \mu \mathrm{M} \\
2.0 \mu \mathrm{M}\end{array}$ & natural water & [95] \\
\hline 4 & $S^{2-}$ & Cu2+@MPA-Cu NCs & $350 / 610$ & turn-off & $0-600 \mu \mathrm{M}$ & $26.3 \mathrm{nM}$ & food additives & [92] \\
\hline
\end{tabular}


Table 3. Cont.

\begin{tabular}{|c|c|c|c|c|c|c|c|c|}
\hline No & Analytes & Sensors & $\begin{array}{c}\text { Ex./Em. } \\
\text { Maxima (nm) }\end{array}$ & $\begin{array}{l}\text { Sensing } \\
\text { Mechanism }\end{array}$ & Linear Range & $\begin{array}{c}\text { Limit of } \\
\text { Detection (LOD) }\end{array}$ & Real Sample & Ref. \\
\hline 5 & $\mathrm{~S}^{2-}$ and $\mathrm{H}_{2} \mathrm{~S}$ & Cu NCs-CQD & $365 / 469,622$ & ratiometric & $26-128 \mathrm{nM}$ & $4.3 \mathrm{nM}$ & - & [96] \\
\hline 6 & $S^{2-}$ & $\mathrm{Cu} \mathrm{NCs}$ & $326 / 422$ & turn-on & 5-110 $\mu \mathrm{M}$ & $0.286 \mu \mathrm{M}$ & $\begin{array}{l}\text { tap water and } \\
\text { river water }\end{array}$ & [10] \\
\hline
\end{tabular}
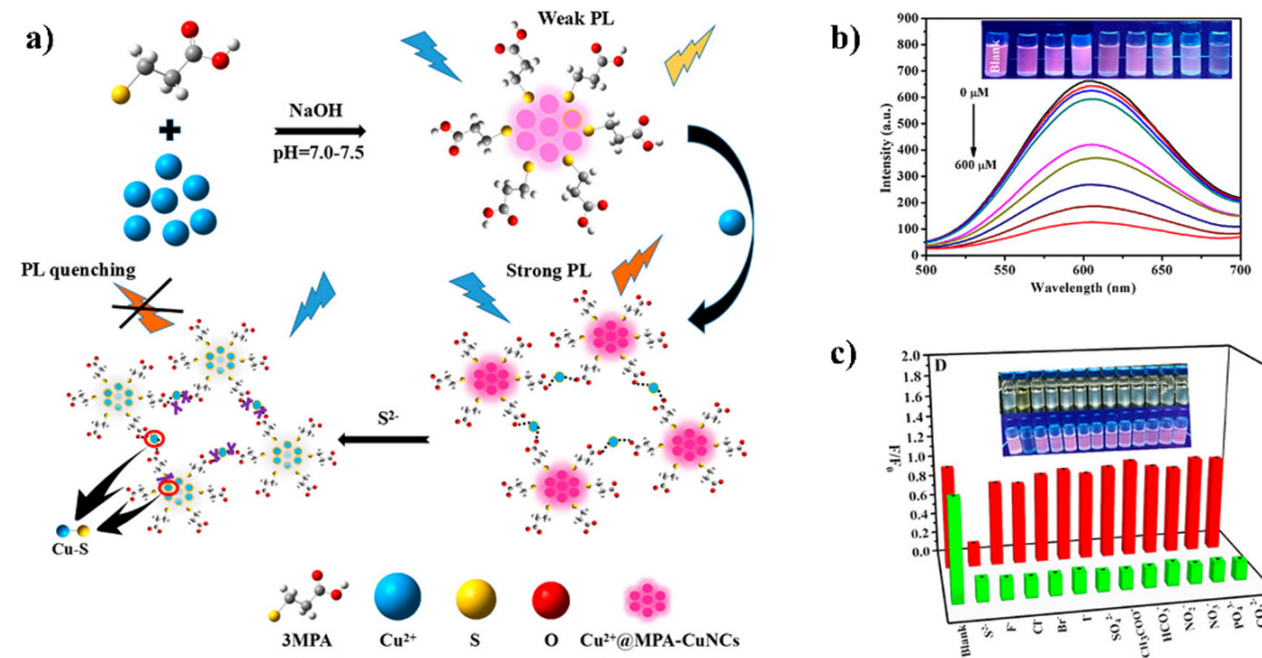

c)

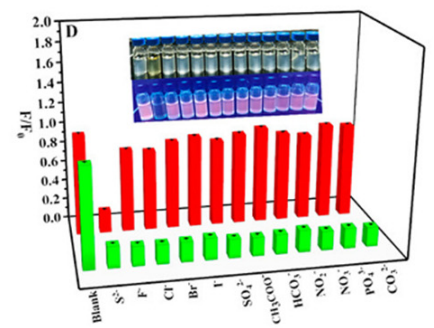

Figure 6. (a) Schematic illustration of the preparation of MPA-Capped Cu NCs and the aggregation induced PL weakening of $\mathrm{Cu}^{2+} @ \mathrm{MPA}-\mathrm{Cu}$ NCs in the presence of $\mathrm{S}^{2-}$; (b) fluorescence emission spectra of $\mathrm{Cu}^{2+} @ \mathrm{MPA}-\mathrm{Cu} \mathrm{NCs}$ in the presence of various concentrations of $\mathrm{S}^{2-}$ in Tris- $\mathrm{HCl}$ buffer solution; (c) effect of different anions on the fluorescence intensity of $\mathrm{Cu}^{2+} @ \mathrm{MPA}-\mathrm{Cu}$ NCs (red pillars), and the influence on the sensor in the presence of different anions coexisting with $\mathrm{S}^{2-}$ ions (green pillars).

\subsection{Others}

$\mathrm{Cu}$ NCs with their fascinating fluorescence properties as well as desirable stability have also been widely employed as sensing probes to determine aromatic compounds (Table 4). Trinitrotoluene (TNT), a popular explosive commonly used in military work, is indeed a dangerous contaminant in water. For the detection of TNT, a luminescent sensor was established by embedding copper nanoclusters ( $\mathrm{Cu}$ NCs) into metal-organic frameworks (MOF) ZIF-8 [36]. Thanks to the confinement-assisted emission enhancement similar to AIE of fluorescence, the stability and emission intensity of the composite was largely improved, with an orange-color emission peak at $600 \mathrm{~nm}$ (Figure 7a). This $\mathrm{Cu}$ NC/ZIF-8 hybrid exhibited capability of detecting trace amounts of TNT, since it was selectively quenched in the presence of TNT. Similarly, there has also been an urgent need for the facile and sensitive detection of picric acid (2,4,6- trinitrophenol, PA). Patel et al. [37] reported an analytical system for PA based on the fluorescence quenching of glutathione stabilized copper nanoclusters and a vitamin B6 cofactor pyridoxamine (PM-GSH-Cu NCs) (Figure $\mathrm{7b}$ ). This nanoprobe exhibited excellent sensitivity and selectivity to PA in different solutions and real samples including tap water, river water and matchstick. To be specific, it could detect PA down to $27.4 \times 10^{-7} \mathrm{M}$, and the paper strips based on this nanoprobe could determine PA with the naked eye at as low as $1 \mu \mathrm{M}$.

Artificial food coloring has contributed greatly to the food manufacturing industry to increase the attractiveness of food by vivid colors. Due to the looming danger and risks to human health, some artificial colorants are banned from being added in food, while the use of others in food are strictly regulated. Quinoline yellow (QY) belongs to the one of the above two categories in various countries that ban colorants and strictly regulate substances. Analytical methods based on $\mathrm{Cu}$ NCs have been thus developed 
toward quinoline yellow in food products. Sivasankaran et al. reported their successful construction of a fluorescent-based probe for QY [97]. Owing to the quenching effect, the blue-fluorescence-emitting-L-cysteine stabilized Cu NCs (L-Cys-Cu NCs) demonstrated excellent sensitivity and selectivity toward QY with a low detection limit of $0.11 \mu \mathrm{M}$ and a linear concentration range between 5.50 and $0.20 \mu \mathrm{M}$. Cu NCs-based sensing probes or systems have also been used in detection and monitoring of overuse or abuse of broadspectrum antibiotics. An ultrasensitive biosensor based on glutathione-capped copper nanoclusters (GSH-Cu NCs) was designed to determine the trace level of furazolidone in the environment and control the overuse [98]. The blue-emitting fluorescent probe was prepared in a very short time. Due to the inner filter effect and static quenching between GSH-Cu NCs and furazolidone, the as-prepared probe exhibited a favorable linear range from 0.05 to $60 \mu \mathrm{M}$ and a low detection limit at $0.012 \mu \mathrm{M}$. Furthermore, $\mathrm{Cu}$ NCs have also proven effectiveness in the detection of residues of 2,6-pyridinedicarboxylic acid (DPA) in the environment, which is notorious for its hazards toward human health and safety, as well as in vulnerable ecosystems. A portable sensing strategy was developed based on the $\mathrm{Cu}$ NC fluorescent test strip. The as-fabricated ratiometric sensing probe (GSH-Cu $\mathrm{NCs} / \mathrm{Eu}^{3+}$ ) demonstrated its sensitivity, timeliness and convenience in determining DPA in the complicated solution with an ultra-low detection limit of $8 \mathrm{nM}$ [99].
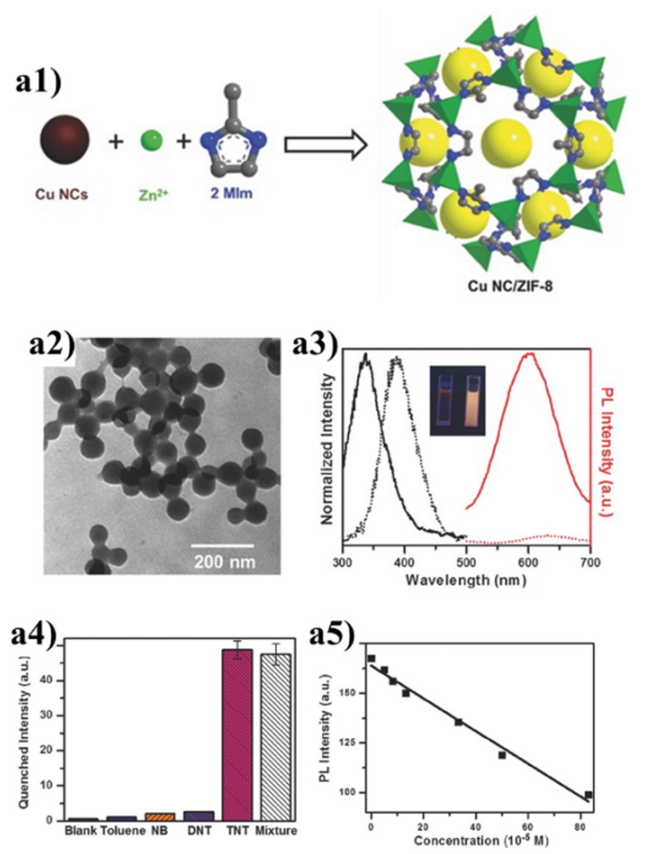

(a) b1)
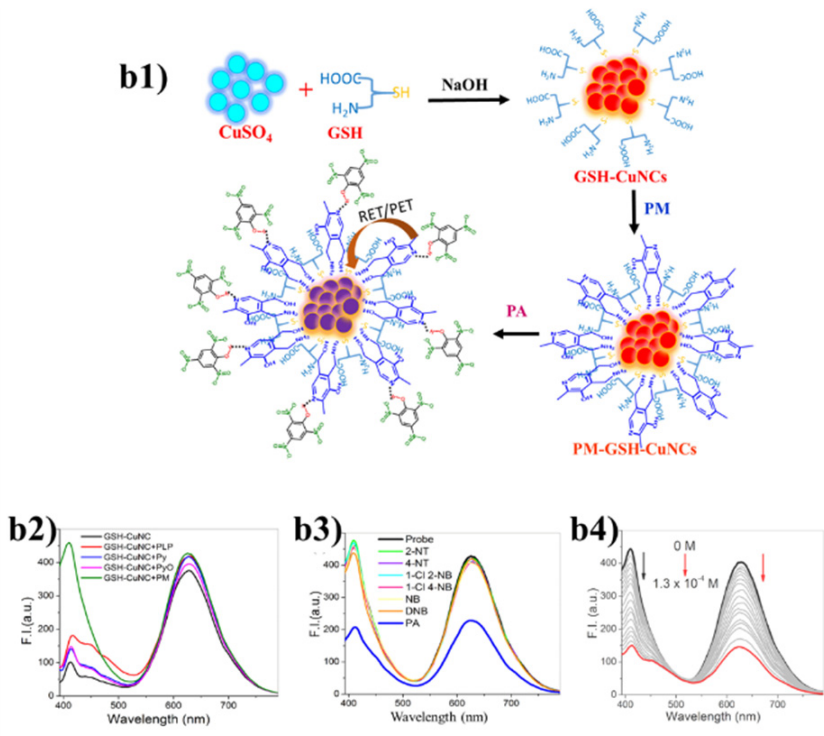

b5)

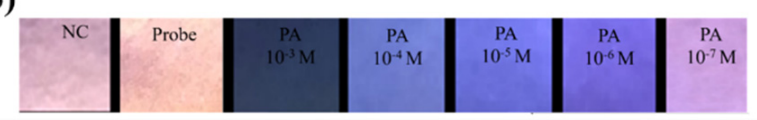

(b)

Figure 7. (a) (a1) Schematic illustration of the synthesis of $\mathrm{Cu}$ NC/ZIF-8 composites from Zn ${ }^{2+}$ ions, 2 Mlm and Cu NCs; (a2) TEM images of Cu NC/ZIF-8 composites; (a3) PL (red, excited at $365 \mathrm{~nm}$ ) and PLE (black, detection wavelength $600 \mathrm{~nm}$ ) spectra of $\mathrm{Cu}$ NCs (dotted lines) and Cu NC/ZIF-8 composites (solid lines); (a4) the decrease in PL intensity of $\mathrm{Cu}$ NC/ZIF-8 composites to blank, toluene, NB, DNT, TNT, and the mixture of all above (concentration of all compounds $\left.500 \times 10^{-6} \mathrm{M}\right)$; (a5) Linear relationship between the PL intensity of $\mathrm{Cu}$ NC/ZIF-8 composites and the concentration of TNT; (b) (b1) Schematic representation for the synthesis of GSH-CuNCs and its interaction with PM and followed by with PA; (b2) fluorescent spectral changes of GSH-CuNCs upon addition of various vitamin B6 cofactors; (b3) fluorescence spectral changes of PM-GSH-CuNCs in the presence of various nitro-aromatics; (b4) fluorescence spectral changes of PM-GSH-CuNCs upon addition of increasing [PA]; (b5) fluorescence color changes of the modified paper strips upon interaction with different concentrations of PA $\left(1 \mathrm{mM}\right.$ to $\left.10^{-7} \mathrm{M}\right)$ observed under UV light at $365 \mathrm{~nm}$. 
Table 4. List of fluorescent probes based on $\mathrm{Cu}$ NCs for detection of other analytes.

\begin{tabular}{|c|c|c|c|c|c|c|c|c|}
\hline No & Analytes & Sensors & $\begin{array}{c}\text { Ex./Em. } \\
\text { Maxima }(\mathrm{nm})\end{array}$ & $\begin{array}{c}\text { Sensing } \\
\text { Mechanism }\end{array}$ & Linear Range & $\begin{array}{c}\text { Limit of } \\
\text { Detection (LOD) }\end{array}$ & Real Sample & Ref. \\
\hline 1 & picric acid & $\mathrm{Cu}$ NCs-CA & $393 / 480$ & turn-off & $1-80 \mu \mathrm{M}$ & $0.14 \mu \mathrm{M}$ & $\begin{array}{c}\text { tap water, lake } \\
\text { water and river } \\
\text { water }\end{array}$ & [22] \\
\hline 2 & trinitrophenol & DNA-Cu NCs & $340 / 627$ & turn-off & $0.1-100 \mu \mathrm{M}$ & $0.03 \mu \mathrm{M}$ & water samples & [44] \\
\hline 3 & picric acid & PM-GSH-Cu NCs & $360 / 625$ & turn-off & $9.9-43 \mu \mathrm{M}$ & $2.74 \mu \mathrm{M}$ & $\begin{array}{l}\text { water and } \\
\text { matchstick }\end{array}$ & [37] \\
\hline 4 & picric acid & Cys-Cu NCs & $370 / 494$ & turn-off & $2.5-25 \mathrm{mM}$ & $0.19 \mathrm{mM}$ & $\begin{array}{c}\text { tap and lake } \\
\text { water }\end{array}$ & [100] \\
\hline 5 & trinitrotoluene & CuNC/ZIF-8 & $365 / 600$ & turn-off & $5-80 \mu \mathrm{M}$ & $8.5 \mu \mathrm{M}$ & tap water & [36] \\
\hline 6 & picric acid & $\mathrm{Cu}$ NCs & $350 / 430$ & turn-off & $2-40 \mathrm{mM}$ & $0.98 \mathrm{mM}$ & water samples & [101] \\
\hline 7 & $\begin{array}{l}\text { quinoline } \\
\text { yellow }\end{array}$ & L-Cys-Cu NCs & $380 / 422,617$ & ratiometric & $0.2-5.5 \mu \mathrm{M}$ & $110 \mathrm{nM}$ & $\begin{array}{c}\text { candies and soft } \\
\text { drink }\end{array}$ & [97] \\
\hline 8 & furazolidone & GSH-Cu NCs & $366 / 426$ & turn off & $0.05-60 \mu \mathrm{M}$ & $12 \mathrm{nM}$ & aqueous sample & [98] \\
\hline 9 & DPA & GSH-Cu NCs & $380 / 422,617$ & ratiometric & 0-20 $\mu \mathrm{M}$ & $8 \mathrm{nM}$ & aqueous sample & [99] \\
\hline 10 & quinolones & Cys-Cu NCs & $368 / 475$ & turn on & $0.5-40 \mu \mathrm{M}$ & $8 \mathrm{nM}$ & tablets & [102] \\
\hline 11 & $\begin{array}{l}\text { Sudan dyes I } \\
\text { Sudan dyes II } \\
\text { Sudan dyes III } \\
\text { Sudan dyes IV }\end{array}$ & PEI-Cu NCs & $355 / 480$ & turn off & $\begin{array}{l}0.1-30 \mu \mathrm{M} \\
0.1-30 \mu \mathrm{M} \\
0.1-25 \mu \mathrm{M} \\
0.1-25 \mu \mathrm{M}\end{array}$ & $\begin{array}{l}65 \mathrm{nM} \\
70 \mathrm{nM} \\
45 \mathrm{nM} \\
50 \mathrm{nM}\end{array}$ & $\begin{array}{l}\text { chilli powder } \\
\text { sample }\end{array}$ & [103] \\
\hline 12 & Bisphenol A & BSA-Cu NCs & $\begin{array}{l}\text { chemilumi- } \\
\text { nescence }\end{array}$ & turn off & $0.001-10 \mu \mathrm{M}$ & $0.12 \mathrm{nM}$ & water sample & [104] \\
\hline 13 & Melamine & T30-Cu NCs & $345 / 598$ & turn on & $0.1-6 \mu \mathrm{M}$ & $95 \mathrm{nM}$ & Milk & [105] \\
\hline
\end{tabular}

\section{Conclusions and Perspectives}

This review summarized and reported the latest development of fluorescent copper nanoclusters utilized in monitoring various types of environmental contaminants. Despite the fascinating advances, there is still a long and arduous way ahead in further improving $\mathrm{Cu}$ NCs to make them ideal materials for pollutant detection, quantitative determination, and, even, decomposition and removal. Firstly, the sizes of the current $\mathrm{Cu}$ NCs designed fall into a rather wide range, and the desirable optical properties of most $\mathrm{Cu}$ NCs heavily rely on excitation. Both of these two aspects may largely constrain the possibility of efficient application of $\mathrm{Cu}$ NCs in environmental analysis on a large scale. Secondly, efforts are imperative to further enhance the chemical and optical stability, as well as quantum yield of $\mathrm{Cu}$ NCs, so as to improve their feasibility as sensors in more complex, real environments, even with complicated, interfering factors. Lastly, the functions of the current probes are expected to be extended from pure detection of environmental pollutants to simultaneous detection, degradation and, even, removal.

Author Contributions: Investigation, Y.X., Z.C. and M.L.; Writing-original draft, Y.X. and Z.C.; Methodology, Y.X.; Conceptualization, Funding acquisition and Writing-review\& editing, H.H. and C.X. All authors have read and agreed to the published version of the manuscript.

Funding: This research is supported by the Foshan Medicine Dengfeng Project of China (2019-2021), Foshan Municipal Government (CP-013-2020). It is also partially supported by the grant from the University of Macau (MYRG2020-00230-ICMS).

Institutional Review Board Statement: Not applicable.

Informed Consent Statement: Not applicable.

Data Availability Statement: No new data were created or analyzed in this study. Data sharing is not applicable to this article.

Conflicts of Interest: The authors declare no conflict of interest. 


\section{References}

1. Jin, R.; Zeng, C.; Zhou, M.; Chen, Y. Atomically Precise Colloidal Metal Nanoclusters and Nanoparticles: Fundamentals and Opportunities. Chem. Rev. 2016, 116, 10346-10413. [CrossRef] [PubMed]

2. Du, Y.; Sheng, H.; Astruc, D.; Zhu, M. Atomically Precise Noble Metal Nanoclusters as Efficient Catalysts: A Bridge between Structure and Properties. Chem. Rev. 2019, 120, 526-622. [CrossRef] [PubMed]

3. Liu, X.; Astruc, D. Atomically precise copper nanoclusters and their applications. Coord. Chem. Rev. 2018, 359, 112-126. [CrossRef]

4. Wang, Z.; Chen, B.; Rogach, A.L. Synthesis, optical properties and applications of light-emitting copper nanoclusters. Nanoscale Horiz. 2017, 2, 135-146. [CrossRef] [PubMed]

5. Baghdasaryan, A.; Bürgi, T. Copper nanoclusters: Designed synthesis, structural diversity, and multiplatform applications. Nanoscale 2021, 13, 6283-6340. [CrossRef] [PubMed]

6. Lai, W.F.; Wong, W.T.; Rogach, A.L. Development of Copper Nanoclusters for in vitro and in vivo Theranostic Applications. Adv. Mater. 2020, 32, 1906872. [CrossRef]

7. Shahsavari, S.; Hadian-Ghazvini, S.; Hooriabad Saboor, F.; Menbari Oskouie, I.; Hasany, M.; Simchi, A.; Rogach, A.L. Ligand functionalized copper nanoclusters for versatile applications in catalysis, sensing, bioimaging, and optoelectronics. Mater. Chem. Front. 2019, 3, 2326-2356. [CrossRef]

8. Hu, X.; Liu, T.; Zhuang, Y.; Wang, W.; Li, Y.; Fan, W.; Huang, Y. Recent advances in the analytical applications of copper nanoclusters. TrAC Trends Anal. Chem. 2016, 77, 66-75. [CrossRef]

9. An, Y.; Ren, Y.; Bick, M.; Dudek, A.; Waworuntu, E.H.; Tang, J.; Chen, J.; Chang, B. Highly fluorescent copper nanoclusters for sensing and bioimaging. Biosens. Bioelectron. 2020, 154, 112078. [CrossRef]

10. Zhang, G.; Wang, R.; Shi, L.; Zhang, C.; Zhang, Y.; Zhou, Y.; Dong, C.; Li, G.; Shuang, S. Aggregation/assembly induced emission based on silk fibroin-templated fluorescent copper nanoclusters for "turn-on" detection of $\mathrm{S}^{2-}$. Sens. Actuators B Chem. 2019, 279, 361-368. [CrossRef]

11. Liu, Y.; Yao, D.; Zhang, H. Self-Assembly Driven Aggregation-Induced Emission of Copper Nanoclusters: A Novel Technology for Lighting. ACS Appl. Mater. Interfaces 2017, 10, 12071-12080. [CrossRef]

12. Bagheri, H.; Afkhami, A.; Khoshsafar, H.; Hajian, A.; Shahriyari, A. Protein capped Cu nanoclusters-swcnt nanocomposite as a novel candidate of high performance platform for organophosphates enzymeless biosensor. Biosens. Bioelectron. 2017, 89, 829-836. [CrossRef] [PubMed]

13. $\mathrm{Hu}, \mathrm{X}$; Wang, W.; Huang, Y. Copper nanocluster-based fluorescent probe for sensitive and selective detection of $\mathrm{Hg}\left(\left(^{2+}\right)\right.$ in water and food stuff. Talanta 2016, 154, 409-415. [CrossRef] [PubMed]

14. Wang, M.; Liu, L.; Xie, X.; Zhou, X.; Lin, Z.; Su, X. Single-atom iron containing nanozyme with peroxidase-like activity and copper nanoclusters based ratio fluorescent strategy for acetylcholinesterase activity sensing. Sens. Actuators B Chem. 2020, $313,128023$. [CrossRef]

15. Xia, J.; Wei, X.; Chen, X.; Shu, Y.; Wang, J. Folic acid modified copper nanoclusters for fluorescent imaging of cancer cells with over-expressed folate receptor. Microchim. Acta 2018, 185, 205. [CrossRef]

16. Wang, Y.; Chen, T.; Zhuang, Q.; Ni, Y. Label-free photoluminescence assay for nitrofurantoin detection in lake water samples using adenosine-stabilized copper nanoclusters as nanoprobes. Talanta 2018, 179, 409-413. [CrossRef] [PubMed]

17. Yang, X.; Feng, Y.; Zhu, S.; Luo, Y.; Zhuo, Y.; Dou, Y. One-step synthesis and applications of fluorescent Cu nanoclusters stabilized by l-cysteine in aqueous solution. Anal. Chim. Acta 2014, 847, 49-54. [CrossRef]

18. Goswami, N.; Giri, A.; Bootharaju, M.S.; Xavier, P.L.; Pradeep, T.; Pal, S.K. Copper Quantum Clusters in Protein Matrix: Potential Sensor of $\mathrm{Pb}^{2+}$ Ion. Anal. Chem. 2011, 83, 9676-9680. [CrossRef]

19. Xiaoqing, L.; Ruiyi, L.; Zaijun, L.; Xiulan, S.; Zhouping, W.; Junkang, L. Fast synthesis of copper nanoclusters through the use of hydrogen peroxide additive and their application for the fluorescence detection of $\mathrm{Hg}^{2+}$ in water samples. New J. Chem. 2015, 39, 5240-5248. [CrossRef]

20. Zhong, Y.; Zhu, J.; Wang, Q.; He, Y.; Ge, Y.; Song, C. Copper nanoclusters coated with bovine serum albumin as a regenerable fluorescent probe for copper(II) ion. Microchim. Acta 2014, 182, 909-915. [CrossRef]

21. Lin, Y.-S.; Chiu, T.-C.; Hu, C.-C. Fluorescence-tunable copper nanoclusters and their application in hexavalent chromium sensing. RSC Adv. 2019, 9, 9228-9234. [CrossRef]

22. Bao, Z.; Zhang, K.; Jian, J.; Hu, Z.; Yuan, K.; Shao, H.; Peng, K.; Jiang, Z.; Zapien, J.A.; Yan, Y.; et al. Strongly fluorescent cysteamine-coated copper nanoclusters as a fluorescent probe for determination of picric acid. Microchim. Acta 2018, $185,507$. [CrossRef] [PubMed]

23. Shellaiah, M.; Simon, T.; Thirumalaivasan, N.; Sun, K.W.; Ko, F.H.; Wu, S.P. Cysteamine-capped gold-copper nanoclusters for fluorometric determination and imaging of chromium(VI) and dopamine. Mikrochim. Acta 2019, 186, 788. [CrossRef]

24. Khonkayan, K.; Sansuk, S.; Srijaranai, S.; Tuntulani, T.; Saiyasombat, C.; Busayaporn, W.; Ngeontae, W. New approach for detection of chromate ion by preconcentration with mixed metal hydroxide coupled with fluorescence sensing of copper nanoclusters. Microchim. Acta 2017, 184, 2965-2974. [CrossRef]

25. Huang, H.; Li, H.; Feng, J.-J.; Feng, H.; Wang, A.-J.; Qian, Z. One-pot green synthesis of highly fluorescent glutathione-stabilized copper nanoclusters for $\mathrm{Fe}^{3+}$ sensing. Sens. Actuators B Chem. 2017, 241, 292-297. [CrossRef]

26. Luo, T.; Zhang, S.; Wang, Y.; Wang, M.; Liao, M.; Kou, X. Glutathione-stabilized Cu nanocluster-based fluorescent probe for sensitive and selective detection of $\mathrm{Hg}^{2+}$ in water. Luminescence 2017, 32, 1092-1099. [CrossRef] [PubMed] 
27. Ma, Y.; Yu, Y.; Lin, B.; Zhang, L.; Cao, Y.; Guo, M. A novel signal amplification strategy based on the use of copper nanoclusters for ratiometric fluorimetric determination of o-phenylenediamine. Mikrochim. Acta 2019, 186, 206. [CrossRef] [PubMed]

28. Feng, J.; Chen, Y.; Han, Y.; Liu, J.; Ma, S.; Zhang, H.; Chen, X. pH-Regulated Synthesis of Trypsin-Templated Copper Nanoclusters with Blue and Yellow Fluorescent Emission. ACS Omega 2017, 2, 9109-9117. [CrossRef] [PubMed]

29. Pandit, S.; Kundu, S. pH-Dependent reversible emission behaviour of lysozyme coated fluorescent copper nanoclusters. J. Lumin. 2020, 228, 117607. [CrossRef]

30. Ghosh, R.; Sahoo, A.K.; Ghosh, S.S.; Paul, A.; Chattopadhyay, A. Blue-Emitting Copper Nanoclusters Synthesized in the Presence of Lysozyme as Candidates for Cell Labeling. ACS Appl. Mater. Interfaces 2014, 6, 3822-3828. [CrossRef]

31. Mao, A.; Wei, C. Cytosine-rich ssDNA-templated fluorescent silver and copper/silver nanoclusters: Optical properties and sensitive detection for mercury(II). Mikrochim. Acta 2019, 186, 541. [CrossRef] [PubMed]

32. Yang, J.; Song, N.; Lv, X.; Jia, Q. UV-light-induced synthesis of PEI-CuNCs based on $\mathrm{Cu}^{2+}$-quenched fluorescence turn-on assay for sensitive detection of biothiols, acetylcholinesterase activity and inhibitor. Sens. Actuators B Chem. 2018, 259, 226-232. [CrossRef]

33. Li, L.; Hou, C.; Li, J.; Yang, Y.; Hou, J.; Ma, Y.; He, Q.; Luo, H.; Huo, D. Fluazinam direct detection based on the inner filter effect using a copper nanocluster fluorescent probe. Anal. Methods 2019, 11, 4637-4643. [CrossRef]

34. Li, Y.; Hu, Y.; He, Y.; Ge, Y.; Song, G.; Zhou, J. Sensitive Naked-eye and Fluorescence Determination of Acetylcholinesterase Activity using Cu/Ag Nanoclusters Based on Inner Filter Effect. ChemistrySelect 2019, 4, 7639-7644. [CrossRef]

35. Dutta, A.; Goswami, U.; Chattopadhyay, A. Probing Cancer Cells through Intracellular Aggregation-Induced Emission Kinetic Rate of Copper Nanoclusters. ACS Appl. Mater. Interfaces 2018, 10, 19459-19472. [CrossRef]

36. Wang, Z.; Chen, R.; Xiong, Y.; Cepe, K.; Schneider, J.; Zboril, R.; Lee, C.-S.; Rogach, A.L. Incorporating Copper Nanoclusters into Metal-Organic Frameworks: Confinement-Assisted Emission Enhancement and Application for Trinitrotoluene Detection. Part. Part. Syst. Charact. 2017, 34, 1700029. [CrossRef]

37. Patel, R.; Bothra, S.; Kumar, R.; Crisponi, G.; Sahoo, S.K. Pyridoxamine driven selective turn-off detection of picric acid using glutathione stabilized fluorescent copper nanoclusters and its applications with chemically modified cellulose strips. Biosens. Bioelectron. 2018, 102, 196-203. [CrossRef]

38. Shen, Z.; Zhang, C.; Yu, X.L.; Li, J.; Liu, B.H.; Zhang, Z.P. A facile stage for $\mathrm{Cu}^{2+}$ ions detection by formation and aggregation of Cu nanoclusters. Microchem. J. 2019, 145, 517-522. [CrossRef]

39. Wang, C.; Cheng, H.; Huang, Y.; Xu, Z.; Lin, H.; Zhang, C. Facile sonochemical synthesis of pH-responsive copper nanoclusters for selective and sensitive detection of $\mathrm{Pb}^{2+}$ in living cells. Analyst 2015, 140, 5634-5639. [CrossRef] [PubMed]

40. Li, J.; Fu, W.; Bao, J.; Wang, Z.; Dai, Z. Fluorescence Regulation of Copper Nanoclusters via DNA Template Manipulation toward Design of a High Signal-to-Noise Ratio Biosensor. ACS Appl. Mater. Interfaces 2018, 10, 6965-6971. [CrossRef]

41. He, J.-L.; Wang, X.-X.; Mei, T.-T.; Wu, L.; Zeng, J.-L.; Wang, J.-H.; Wang, J.; Yu, D.; Cao, Z. DNA-templated copper nanoclusters obtained via TdT isothermal nucleic acid amplification for mercury(ii) assay. Anal. Methods 2019, 11, 4165-4172. [CrossRef]

42. Su, Y.-T.; Lan, G.-Y.; Chen, W.-Y.; Chang, H.-T. Detection of Copper Ions Through Recovery of the Fluorescence of DNA-Templated Copper/Silver Nanoclusters in the Presence of Mercaptopropionic Acid. Anal. Chem. 2010, 82, 8566-8572. [CrossRef]

43. Ou, L.J.; Huang, J.K.; Lv, X.L.; Huang, N. DsDNA-templated fluorescent copper nanoclusters for ultrasensitive label-free detection of $\mathrm{Pb}^{2+}$ ion. Chin. J. Anal. Lab. 2016, 35, 899-902. [CrossRef]

44. Li, H.; Chang, J.; Hou, T.; Ge, L.; Li, F. A facile, sensitive, and highly specific trinitrophenol assay based on target-induced synergetic effects of acid induction and electron transfer towards DNA-templated copper nanoclusters. Talanta 2016, 160, 475-480. [CrossRef] [PubMed]

45. Bhamore, J.R.; Jha, S.; Mungara, A.K.; Singhal, R.K.; Sonkeshariya, D.; Kailasa, S.K. One-step green synthetic approach for the preparation of multicolor emitting copper nanoclusters and their applications in chemical species sensing and bioimaging. Biosens. Bioelectron. 2016, 80, 243-248. [CrossRef]

46. Wu, X.; Zhang, F.; Li, Y. Facile synthesis of near-infrared emitting dBSA-templated Cu nanoclusters for sensitive detection of heparin. J. Mater. Chem. B 2018, 6, 5466-5475. [CrossRef] [PubMed]

47. Nematulloev, S.; Huang, R.W.; Yin, J.; Shkurenko, A.; Dong, C.; Ghosh, A.; Alamer, B.; Naphade, R.; Hedhili, M.N.; Maity, P.; et al. $\left[\mathrm{Cu}_{15}\left(\mathrm{PPh}_{3}\right)_{6}(\mathrm{PET})_{13}\right]^{2+}:$ A Copper Nanocluster with Crystallization Enhanced Photoluminescence. Small 2021, 17, 2006839. [CrossRef]

48. Dong, W.; Sun, C.; Sun, M.; Ge, H.; Asiri, A.M.; Marwani, H.M.; Ni, R.; Wang, S. Fluorescent Copper Nanoclusters for the Iodide-Enhanced Detection of Hypochlorous Acid. ACS Appl. Nano Mater. 2019, 3, 312-318. [CrossRef]

49. Shojaeifard, Z.; Heidari, N.; Hemmateenejad, B. Bimetallic AuCu nanoclusters-based florescent chemosensor for sensitive detection of $\mathrm{Fe}^{3+}$ ) in environmental and biological systems. Spectrochim. Acta. Part A Mol. Biomol. Spectrosc. 2019, 209, 202-208. [CrossRef]

50. Luo, M.; Wei, J.; Zhao, Y.; Sun, Y.; Liang, H.; Wang, S.; Li, P. Fluorescent and visual detection of methyl-paraoxon by using boron-and nitrogen-doped carbon dots. Microchem. J. 2020, 154, 104547. [CrossRef]

51. Wei, J.; Yang, Y.; Dong, J.; Wang, S.; Li, P. Fluorometric determination of pesticides and organophosphates using nanoceria as a phosphatase mimic and an inner filter effect on carbon nanodots. Microchim. Acta 2019, 186, 66. [CrossRef]

52. Cao, H.; Chen, Z.; Zheng, H.; Huang, Y. Copper nanoclusters as a highly sensitive and selective fluorescence sensor for ferric ions in serum and living cells by imaging. Biosens. Bioelectron. 2014, 62, 189-195. [CrossRef] 
53. Das, N.K.; Ghosh, S.; Priya, A.; Datta, S.; Mukherjee, S. Luminescent Copper Nanoclusters as a Specific Cell-Imaging Probe and a Selective Metal Ion Sensor. J. Phys. Chem. C 2015, 119, 24657-24664. [CrossRef]

54. Bhamore, J.R.; Deshmukh, B.; Haran, V.; Jha, S.; Singhal, R.K.; Lenka, N.; Kailasa, S.K.; Murthy, Z.V.P. One-step eco-friendly approach for the fabrication of synergistically engineered fluorescent copper nanoclusters: Sensing of $\mathrm{Hg}^{2+}$ ion and cellular uptake and bioimaging properties. New J. Chem. 2018, 42, 1510-1520. [CrossRef]

55. Sahu, D.K.; Singha, D.; Sahu, K. Sensing of iron(III)-biomolecules by surfactant-free fluorescent copper nanoclusters. Sens. Bio-Sens. Res. 2019, 22, 100250. [CrossRef]

56. Boonmee, C.; Promarak, V.; Tuntulani, T.; Ngeontae, W. Cysteamine-capped copper nanoclusters as a highly selective turn-on fluorescent assay for the detection of aluminum ions. Talanta 2018, 178, 796-804. [CrossRef]

57. Han, B.-Y.; Hou, X.-F.; Xiang, R.-C.; Yu, M.-B.; Li, Y.; Peng, T.-T.; He, G.-H. Detection of Lead Ion Based on Aggregation-induced Emission of Copper Nanoclusters. Chin. J. Anal. Chem. 2017, 45, 23-27. [CrossRef]

58. Wang, Y.; Chen, T.; Zhang, Z.; Ni, Y. Cytidine-stabilized copper nanoclusters as a fluorescent probe for sensing of copper ions and hemin. RSC Adv. 2018, 8, 9057-9062. [CrossRef]

59. Yang, J.; Li, Z.; Jia, Q. Anchoring copper nanoclusters to Zn-containing hydroxy double salt: Construction of 2D surface confinement induced enhanced emission toward bio-enzyme sensing and light-emitting diode fabrication. Chem. Commun. 2020, 56, 3081-3084. [CrossRef]

60. Hu, X.; Liu, X.; Zhang, X.; Chai, H.; Huang, Y. One-pot synthesis of the CuNCs/ZIF-8 nanocomposites for sensitively detecting $\mathrm{H}_{2} \mathrm{O}_{2}$ and screening of oxidase activity. Biosens. Bioelectron. 2018, 105, 65-70. [CrossRef] [PubMed]

61. Meng, J.E.S.; Wei, X.; Chen, X.; Wang, J. Confinement of AuAg NCs in a Pomegranate-Type Silica Architecture for Improved Copper Ion Sensing and Imaging. ACS Appl. Mater. Interfaces 2019, 11, 21150-21158. [CrossRef] [PubMed]

62. Yang, J.; Song, N.; Jia, Q. Investigation of the surface confinement effect of copper nanoclusters: Construction of an ultrasensitive fluorescence turn-on bio-enzyme sensing platform. Nanoscale 2019, 11, 21927-21933. [CrossRef] [PubMed]

63. Shi, Y.; Li, W.; Feng, X.; Lin, L.; Nie, P.; Shi, J.; Zou, X.; He, Y. Sensing of mercury ions in Porphyra by Copper @ Gold nanoclusters based ratiometric fluorescent aptasensor. Food Chem. 2021, 344, 128694. [CrossRef]

64. Sun, Y.; Wei, J.; Zou, J.; Cheng, Z.; Huang, Z.; Gu, L.; Zhong, Z.; Li, S.; Wang, Y.; Li, P. Electrochemical detection of methyl-paraoxon based on bifunctional nanozyme with catalytic activity and signal amplification effect. J. Pharm. Anal. 2020. [CrossRef]

65. Wang, W.; Gunasekaran, S. Nanozymes-based biosensors for food quality and safety. TrAC Trends Anal. Chem. 2020, 126, 115841. [CrossRef]

66. Wang, T.; Wang, S.; Cheng, Z.; Wei, J.; Yang, L.; Zhong, Z.; Hu, H.; Wang, Y.; Zhou, B.; Li, P. Emerging core-shell nanostructures for surface-enhanced Raman scattering (SERS) detection of pesticide residues. Chem. Eng. J. 2021, 424, 130323. [CrossRef]

67. Yang, Y.; Wei, Q.; Zou, T.; Kong, Y.; Su, L.; Ma, D.; Wang, Y. Dual-emission ratiometric fluorescent detection of dinotefuran based on sulfur-doped carbon quantum dots and copper nanocluster hybrid. Sens. Actuators B Chem. 2020, 321, 128534. [CrossRef]

68. Chen, S.; Wang, Y.; Feng, L. Specific detection and discrimination of dithiocarbamates using CTAB-encapsulated fluorescent copper nanoclusters. Talanta 2020, 210, 120627. [CrossRef]

69. Li, W.; Li, W.; Hu, Y.; Xia, Y.; Shen, Q.; Nie, Z.; Huang, Y.; Yao, S. A fluorometric assay for acetylcholinesterase activity and inhibitor detection based on DNA-templated copper/silver nanoclusters. Biosens. Bioelectron. 2013, 47, 345-349. [CrossRef]

70. Zhang, H.; Guan, Y.; Li, X.; Lian, L.; Wang, X.; Gao, W.; Zhu, B.; Liu, X.; Lou, D. Ultrasensitive Biosensor for Detection of Mercury(II) Ions Based on DNA-Cu Nanoclusters and Exonuclease III-assisted Signal Amplification. Anal. Sci. 2018, 34, 1155-1161. [CrossRef]

71. Liu, H.; Gao, X.; Zhuang, X.; Tian, C.; Wang, Z.; Li, Y.; Rogach, A.L. A specific electrochemiluminescence sensor for selective and ultra-sensitive mercury(ii) detection based on dithiothreitol functionalized copper nanocluster/carbon nitride nanocomposites Analyst 2019, 144, 4425-4431. [CrossRef] [PubMed]

72. Cai, Z.; Zhu, R.; Pang, S.; Tian, F.; Zhang, C. One-step Green Synthetic Approach for the Preparation of Orange Light Emitting Copper Nanoclusters for Sensitive Detection of Mercury(II) Ions. ChemistrySelect 2020, 5, 165-170. [CrossRef]

73. Maruthupandi, M.; Thiruppathi, D.; Vasimalai, N. One minute synthesis of green fluorescent copper nanocluster: The preparation of smartphone aided paper-based kit for on-site monitoring of nanomolar level mercury and sulfide ions in environmental samples. J. Hazard. Mater. 2020, 392, 122294. [CrossRef]

74. Benavides, J.; Quijada-Garrido, I.; Garcia, O. The synthesis of switch-off fluorescent water-stable copper nanocluster $\mathrm{Hg}\left({ }^{2+}\right)$ sensors via a simple one-pot approach by an in situ metal reduction strategy in the presence of a thiolated polymer ligand template. Nanoscale 2020, 12, 944-955. [CrossRef] [PubMed]

75. Meyer, D.N.; Crofts, E.J.; Akemann, C.; Gurdziel, K.; Farr, R.; Baker, B.B.; Weber, D.; Baker, T.R. Developmental exposure to Pb ${ }^{2+}$ induces transgenerational changes to zebrafish brain transcriptome. Chemosphere 2020, 244, 125527. [CrossRef]

76. Vineeth Daniel, P.; Kamthan, M.; Gera, R.; Dogra, S.; Gautam, K.; Ghosh, D.; Mondal, P. Chronic exposure to Pb ${ }^{2+}$ perturbs ChREBP transactivation and coerces hepatic dyslipidemia. FEBS Lett. 2019, 593, 3084-3097. [CrossRef] [PubMed]

77. Li, W.; Hu, X.; Li, Q.; Shi, Y.; Zhai, X.; Xu, Y.; Li, Z.; Huang, X.; Wang, X.; Shi, J.; et al. Copper nanoclusters @ nitrogen-doped carbon quantum dots-based ratiometric fluorescence probe for lead (II) ions detection in porphyra. Food Chem. 2020, $320,126623$. [CrossRef]

78. Bai, H.; Tu, Z.; Liu, Y.; Tai, Q.; Guo, Z.; Liu, S. Dual-emission carbon dots-stabilized copper nanoclusters for ratiometric and visual detection of $\mathrm{Cr}_{2} \mathrm{O}_{7}\left({ }^{2-}\right)$ ions and $\mathrm{Cd}\left({ }^{2+}\right)$ ions. J. Hazard. Mater. 2020, 386, 121654. [CrossRef] 
79. Maayan, G.; Behar, A.E.; Sabater, L.; Baskin, M.; Hureau, C. A Water-Soluble Peptoid Chelator that Can Remove Cu ${ }^{2+}$ from Amyloid- $\beta$ and Stop the Formation of Reactive Oxygen Species Associated with Alzheimer's Disease. Angew. Chem. Int. Ed. 2021, 60, 2-12. [CrossRef]

80. Migliorini, C.; Porciatti, E.; Luczkowski, M.; Valensin, D. Structural characterization of $\mathrm{Cu}^{2+}, \mathrm{Ni}^{2+}$ and $\mathrm{Zn}^{2+}$ binding sites of model peptides associated with neurodegenerative diseases. Coord. Chem. Rev. 2012, 256, 352-368. [CrossRef]

81. Liu, Z.C.; Qi, J.W.; Hu, C.; Zhang, L.; Song, W.; Liang, R.P.; Qiu, J.D. Cu nanoclusters-based ratiometric fluorescence probe for ratiometric and visualization detection of copper ions. Anal. Chim. Acta 2015, 895, 95-103. [CrossRef] [PubMed]

82. Liu, R.; Zuo, L.; Huang, X.; Liu, S.; Yang, G.; Li, S.; Lv, C. Colorimetric determination of lead(II) or mercury(II) based on target induced switching of the enzyme-like activity of metallothionein-stabilized copper nanoclusters. Mikrochim. Acta 2019, 186, 250. [CrossRef]

83. Wang, H.-B.; Bai, H.-Y.; Wang, Y.-S.; Gan, T.; Liu, Y.-M. Highly selective fluorimetric and colorimetric sensing of mercury(II) by exploiting the self-assembly-induced emission of 4-chlorothiophenol capped copper nanoclusters. Microchim. Acta 2020, 187. [CrossRef] [PubMed]

84. Xu, J.; Han, B. Synthesis of Protein-Directed Orange/Red-Emitting Copper Nanoclusters via Hydroxylamine Hydrochloride Reduction Approach and Their Applications on $\mathrm{Hg}^{2+}$ Sensing. Nano 2016, 11, 1650108. [CrossRef]

85. Cai, Y.; Wang, J.; Niu, L.; Zhang, Y.; Liu, X.; Liu, C.; Yang, S.; Qi, H.; Liu, A. Selective colorimetric sensing of sub-nanomolar Hg ${ }^{2+}$ based on its significantly enhancing peroxidase mimics of silver/copper nanoclusters. Analyst 2021, 146, 4630-4635. [CrossRef] [PubMed]

86. Li, Z.; Pang, S.; Wang, M.; Wu, M.; Li, P.; Bai, J.; Yang, X. Dual-emission carbon dots-copper nanoclusters ratiometric photoluminescent nano-composites for highly sensitive and selective detection of $\mathrm{Hg}^{2+}$. Ceram. Int. 2021, 47, 18238-18245. [CrossRef]

87. Zhong, K.; Hao, C.; Liu, H.; Yang, H.; Sun, R. Synthesis of dual-emissive ratiometric probe of BSA-Au NCs and BSA-Cu NCs and their sensitive and selective detection of copper and mercury ions. J. Photochem. Photobiol. A Chem. 2021, 408. [CrossRef]

88. Feng, D.-Q.; Zhu, W.; Liu, G.; Wang, W. Dual-modal light scattering and fluorometric detection of lead ion by stimuli-responsive aggregation of BSA-stabilized copper nanoclusters. RSC Adv. 2016, 6, 96729-96734. [CrossRef]

89. Li, M.; Cai, Y.; Peng, C.; Wei, X.; Wang, Z. DNA dendrimer-templated copper nanoparticles: Self-assembly, aggregation-induced emission enhancement and sensing of lead ions. Microchim. Acta 2021, 188. [CrossRef]

90. Cao, X.; Bai, Y.; Liu, F.; Li, F.; Luo, Y. 'Turn-off' fluorescence strategy for determination of hexavalent chromium ions based on copper nanoclusters. Luminescence 2020, 36, 229-236. [CrossRef]

91. Li, D.; Li, B.; Yang, S.I. A selective fluorescence turn-on sensing system for evaluation of $\mathrm{Cu}^{2+}$ polluted water based on ultra-fast formation of fluorescent copper nanoclusters. Anal. Methods 2015, 7, 2278-2282. [CrossRef]

92. Wang, D.; Wang, Z.; Wang, X.; Zhuang, X.; Tian, C.; Luan, F.; Fu, X. Functionalized Copper Nanoclusters-Based Fluorescent Probe with Aggregation-Induced Emission Property for Selective Detection of Sulfide Ions in Food Additives. J. Agric. Food Chem. 2020, 68, 11301-11308. [CrossRef] [PubMed]

93. Li, D.; Wang, G.; Peng, Y.; Chen, Z.; Gao, X.; Cheng, L.; Mei, X. Development of ratiometric sensing and white light-harvesting materials based on all-copper nanoclusters. Nanoscale Adv. 2019, 1, 1086-1095. [CrossRef]

94. Chen, P.C.; Li, Y.C.; Ma, J.Y.; Huang, J.Y.; Chen, C.F.; Chang, H.T. Size-tunable copper nanocluster aggregates and their application in hydrogen sulfide sensing on paper-based devices. Sci. Rep. 2016, 6, 24882. [CrossRef]

95. Shojaeifard, Z.; Hemmateenejad, B.; Shamsipur, M.; Ahmadi, R. Dual fluorometric and colorimetric sensor based on quenching effect of copper (II) sulfate on the copper nanocluster for determination of sulfide ion in water samples. J. Photochem. Photobiol. A Chem. 2019, 384, 112030. [CrossRef]

96. Wen, Z.; Song, S.; Hu, T.; Wang, C.; Qu, F.; Wang, P.; Yang, M. A dual emission nanocomposite prepared from copper nanoclusters and carbon dots as a ratiometric fluorescent probe for sulfide and gaseous $\mathrm{H}_{2} \mathrm{~S}$. Mikrochim. Acta 2019, 186, 258. [CrossRef] [PubMed]

97. Sivasankaran, U.; Radecki, J.; Radecka, H.; Girish Kumar, K. Copper nanoclusters: An efficient fluorescence sensing platform for quinoline yellow. Luminescence 2019, 34, 243-248. [CrossRef]

98. Cai, Z.; Wu, L.; Qi, K.; Deng, C.; Zhang, C. Blue-emitting glutathione-capped copper nanoclusters as fluorescent probes for the highly specific biosensing of furazolidone. Spectrochim. Acta Part A Mol. Biomol. Spectrosc. 2021, 247, 119145. [CrossRef] [PubMed]

99. Zhao, J.; Chen, Y.; Du, P.; Li, J.; Zhang, Z.; Lu, X. Portable smartphone platform integrated with fluorescent test strip based on $\mathrm{Eu}^{3+}$-functionalized copper nanoclusters for on-site visual recognition of a pathogenic biomarker. Sens. Actuators B Chem. 2021, 332, 129495. [CrossRef]

100. Shanmugaraj, K.; John, S.A. Inner filter effect based selective detection of picric acid in aqueous solution using green luminescent copper nanoclusters. New J. Chem. 2018, 42, 7223-7229. [CrossRef]

101. Zhang, W.J.; Liu, S.G.; Han, L.; Ling, Y.; Liao, L.L.; Mo, S.; Luo, H.Q.; Li, N.B. Copper nanoclusters with strong fluorescence emission as a sensing platform for sensitive and selective detection of picric acid. Anal. Methods 2018, 10, 4251-4256. [CrossRef]

102. Lian, N.; Zhang, Y.; Liu, D.; Tang, J.; Wu, H. Copper nanoclusters as a turn-on fluorescent probe for sensitive and selective detection of quinolones. Microchem. J. 2021, 164, 105989. [CrossRef]

103. Ling, Y.; Li, J.X.; Qu, F.; Li, N.B.; Luo, H.Q. Rapid fluorescence assay for Sudan dyes using polyethyleneimine-coated copper nanoclusters. Microchim. Acta 2014, 181, 1069-1075. [CrossRef] 
104. Xu, S.; Deng, M.; Sui, Y.; Zhang, Y.; Chen, F. Ultrasensitive determination of bisphenol A in water by inhibition of copper nanoclusters-enhanced chemiluminescence from the luminol-KMnO ${ }_{4}$ system. RSC Adv. 2014, 4, 44644-44649. [CrossRef]

105. Zhu, H.; Dai, W.; Yu, X.; Xu, J.; Chen, H. Poly thymine stabilized copper nanoclusters as a fluorescence probe for melamine sensing. Talanta 2015, 144, 642-647. [CrossRef] 